Onorden

\title{
Best Available Technique
}

Buller från bergtäkter

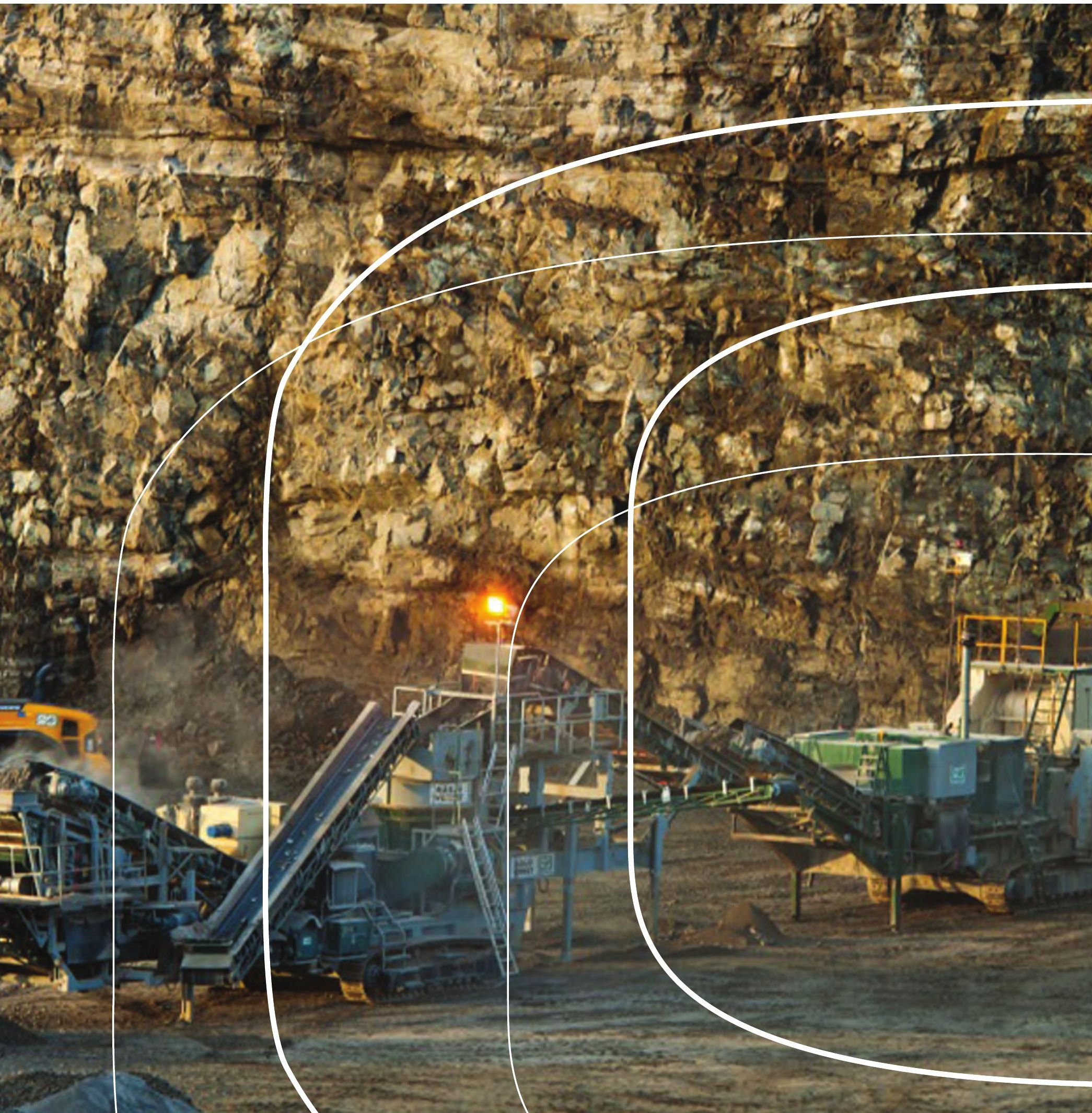



4 norden 



\section{Best Available Technique}

Buller från bergtäkter

Pär Wigholm, Per Åke Nilsson och Örjan Johansson

TemaNord 2013:588 
Best Available Technique

Buller från bergtäkter

Pär Wigholm, Per Åke Nilsson och Örjan Johansson

ISBN 978-92-893-2662-9

http://dx.doi.org/10.6027/TN2013-588

TemaNord 2013:588

(C) Nordiska ministerrådet 2013

Layout: Hanne Lebech

Omslagsfoto: Peter Lidman

Denna rapport är utgiven med finansiellt stöd från Nordiska ministerrådet. Innehållet i rapporten avspeglar inte nödvändigtvis Nordiska ministerrådets synpunkter, åsikter eller rekommendationer.

www.norden.org/sv/publikationer

\section{Det nordiska samarbetet}

Det nordiska samarbetet är ett av världens mest omfattande regionala samarbeten. Det omfattar Danmark, Finland, Island, Norge och Sverige samt Färöarna, Grönland och Åland.

Det nordiska samarbetet är politiskt, ekonomiskt och kulturellt förankrat och är en viktig partner i europeiskt och internationellt samarbete. Den nordiska gemenskapen arbetar för ett starkt Norden i ett starkt Europa.

Det nordiska samarbetet ska stärka nordiska och regionala intressen och värderingar i en global omvärld. Gemensamma värderingar länderna emellan bidrar till att stärka Nordens ställning som en av världens mest innovativa och konkurrenskraftiga regioner.

Nordiska ministerrådet

Ved Stranden 18

DK-1061 København K

Telefon (+45) 33960200

www.norden.org 


\section{Innehåll}

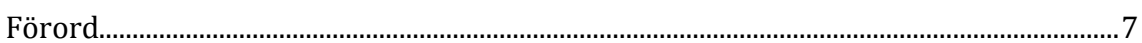

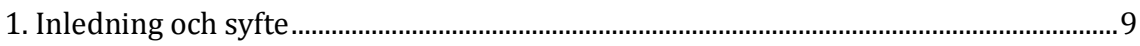

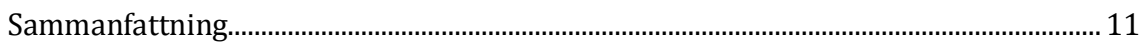

1. Allmänt om ljud och buller ...................................................................................... 13

2. Allmänt om täkter och deras miljöpåverkan ............................................................... 15

2.1 Täkter - Miljöfarlig verksamhet (Svenska förhållanden) ............................. 15

2.2 Vanliga drifttider hos bergtäkter i Sverige......................................................... 16

3. Riktvärden för buller i de nordiska länderna ............................................................... 17

3.1 Riktvärden för externt industribuller i Sverige .............................................. 17

3.2 Riktvärden för externt industribuller i Norge.............................................. 18

3.3 Riktvärden för externt industribuller i Danmark ........................................... 19

3.4 Riktvärden för externt industribuller på Färöarna......................................... 20

3.5 Riktvärden för externt industribuller i Finland................................................ 20

3.6 Riktvärden för externt industribuller på Åland................................................ 21

3.7 Riktvärden för externt industribuller på Island.............................................. 21

3.8 Jämförelse av riktvärden för externt industribuller i de nordiska

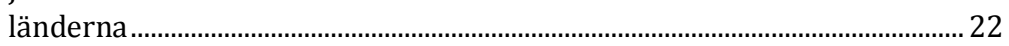

4. Bullerbekämpning allmänt.......................................................................................... 23

4.1 Minska buller vid källan................................................................................. 23

4.2 Förhindra bullerspridning längs utbredningsvägen...................................... 24

4.3 Minska buller vid mottagaren....................................................................... 24

5. Bullerbekämpning i bergtäkter .................................................................................. 27

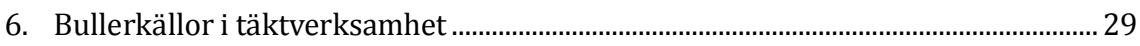

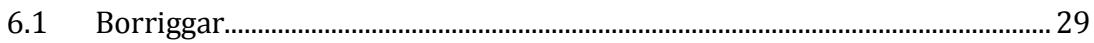

6.2 Bergkrossar ........................................................................................................ 30

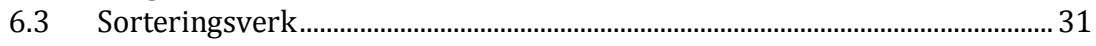

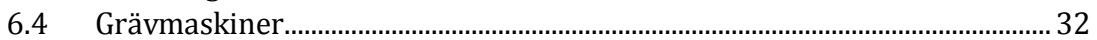

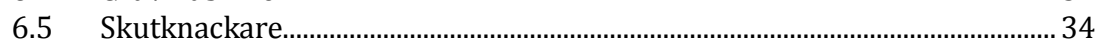

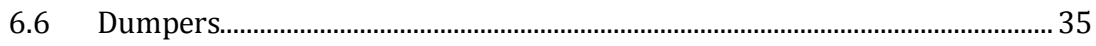

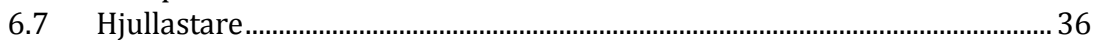

6.8 Utlastning till lastbil och transporter ................................................................ 38

7. Erfarenheter av maskiner i bergtäkter ..................................................................... 41

8. Bästa tillgängliga teknik till bullerreducering från täkter ........................................... 43

9. Beräkning av buller från fiktiv bergtäktverksamhet ................................................... 47

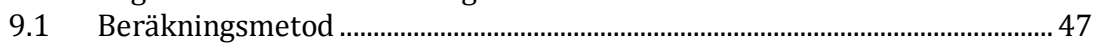

9.2 Underlag/beräkningsutförande .................................................................... 47

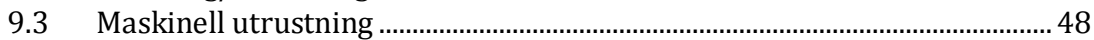

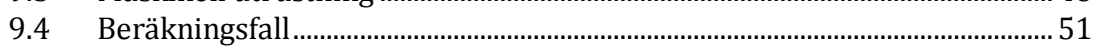

9.5 Beräkningspunkter .................................................................................... 51 


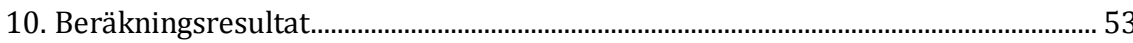

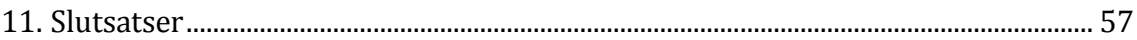

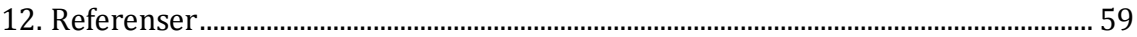

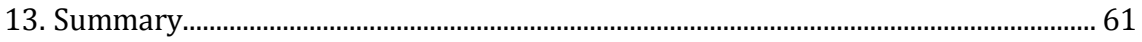




\section{Förord}

ÅF Ljud \& Vibrationer har på uppdrag av Nordiska ministerrådet, utfört en förstudie kring BAT (Best Available Technique) om buller från bergtäkter. Buller är en av de största miljöfrågorna för bergmaterialindustrin som levererar material för att bygga vägar, järnvägar, i anläggnings- och bostadsbyggande samt för användning i vissa kemiska processer och inom miljövård.

Resultatet visar att genom att tillämpa bästa möjliga teknik (Best Available Technique) vid ett systematiskt arbete med buller i bergtäkters planering och pågående verksamhet så är det möjligt att minska betydligt ljudutbredningen till omgivningen. Avståndet från täkt till punkt i omgivningen där riktvärdet överskrids kan halveras för den bullrigaste situationen jämfört med den dämpade. Detta innebär i sin tur att området som överstiger riktvärdet kan teoretiskt, med de rätta topografiska förutsättningarna, minska ned till en fjärdedel genom att tilllämpa bästa möjliga teknik.

Förstudien genomfördes av BAT-gruppen som är en undergrupp till Nordiska ministerrådets arbetsgrupp för hållbar konsumtion och produktion HKP.

November 2013

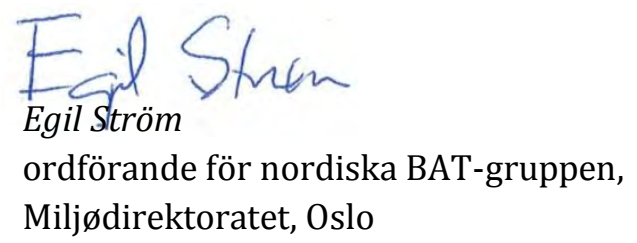





\section{Inledning och syfte}

ÅF Ljud \& Vibrationer har på uppdrag av Nordiska ministerrådet, utfört en förstudie kring BAT (Best Available Technique) om buller från bergtäkter. Bergtäkter är en vanligt förekommande verksamhet i flera nordiska länder.

Rapporten är framtagen i syfte att beskriva hur bullerutbredningen kan variera från en bergtäkt beroende på vilken typ av maskinutrustning som används samt hur man utnyttjar möjligheter att minska bullerutbredningen från verksamheten genom att välja tysta maskiner eller arbetsmetoder samt att styra brytningen på så sätt att bullerskärmning skapas mot berörda områden. 



\section{Sammanfattning}

ÅF Ljud \& Vibrationer har på uppdrag av Nordiska ministerrådet, utfört en förstudie kring BAT (Best Available Technique) om buller från bergtäkter. Buller är en av de största miljöfrågorna för bergmaterialindustrin som levererar material för att bygga vägar, järnvägar, i anläggnings- och bostadsbyggande samt för användning i vissa kemiska processer och inom miljövård. Råvaran är krossat berg, naturgrus. natursand, stenblock och återvunnet material. För att bedriva en täktverksamhet krävs tillstånd och en godkänd miljökonsekvensbeskrivning av berörd myndighet.

Syftet med utredningen är att visa hur bullerutbredningen kan variera från en bergtäkt beroende på val av maskinutrustning och tillämpning av bästa tillgängliga teknik. Riktvärden, villkor och mätmetoder är relativt lika i de Nordiska länderna, men skillnader finns. Resultat och diskussion fokuserar på de ljudeffekter som olika maskiner och verksamheter ger upphov till, samt vad som normalt görs och kan beaktas i en bergtäkt för att minska bullerspridning till omgivningen. Beräknade bullernivåer utgår från uppmätta ljudeffektnivåer för maskiner i drift verksamma i bergtäkter. De kraftigaste kontinuerliga bullerkällorna i en bergtäkt är normalt krossning och bergborrning.

Resultaten redovisas i form av en beräkning av externt buller från en fiktiv bergtäkt utifrån en verklig topografisk modell. Beräkningarna grundas på tabellerade ljudeffektdata på befintliga maskinutrustningar och en antagen brytningsplan. Förväntade ekvivalenta ljudnivåer beräknas till totalt 12 beräkningspunkter omkring täktområdet. I beräkningarna ingår också beräkning av ljudnivåbidraget från lastbilstransporter till och från täktområdet. Beräkningarna avser 11 olika beräkningsfall för en bergtäktsverksamhet där följande parametrar varierats:

- Bullrigaste till tystast möjliga maskinpark inom medelstor täkt.

- Med och utan skärmar/vallar nära maskiner.

- Grusväg alternativt asfaltsbeläggning på transportväg mellan täkt och anslutningspunkt på det allmänna vägnätet.

- Kross- och brytningsverksamhet på oskärmat ytberg jämfört med på täktbotten invid täktkant. 
- Beräkningar med och utan bergborrning. Borrningen är i beräkningarna alltid placerad högt på ytberget, inte på lägre nivå nära täktbotten.

- Beräkningar för maskiner på täktbotten har även utförts med rak, konkav respektive konvex brytningsfront för att visa hur buller sprids med dessa olika geometrier.

Resultatet visar att en tillämpning av "Best Available Technique" d.v.s vid ett systematiskt arbete med buller i bergtäkters planering och pågående verksamhet kan ljudutbredningen till omgivningen minskas betydligt. Avståndet från täkt till punkt i omgivningen där riktvärdet överskrids kan halveras för den bullrigaste situationen jämfört med den dämpade. Detta innebär i sin tur att området som överstiger riktvärdet kan teoretiskt, med rätt topografiska förutsättningar, minska ned till en fjärdedel med användning av "Best Available Technique." 


\section{Allmänt om ljud och buller}

Ljud definieras som tryckutbredning i ett elastiskt medium, vanligen luft, alstrad av en ljudkälla. För att tryckförändringen skall definieras som ljud krävs förutom ljudkälla och utbredningsmedium även en mottagare för ljudet, oftast i form av en levande varelse med ett aktivt hörselorgan.

\section{Figur 1. Ljudtrycksnivåer vid olika aktiviteter}

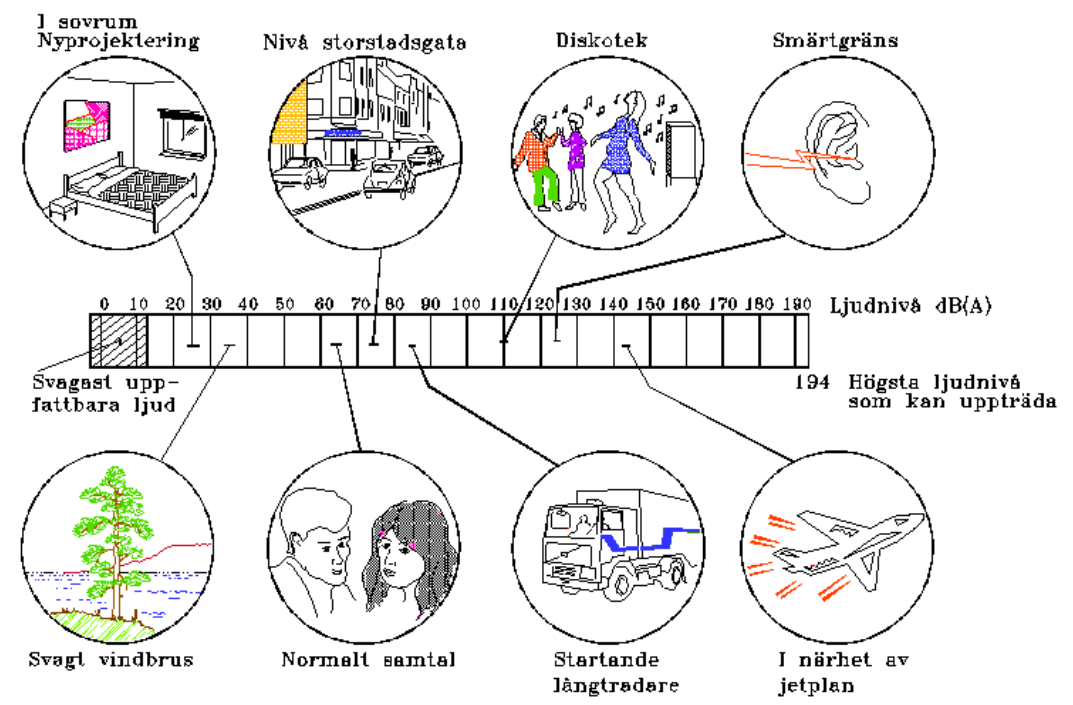

En ökning eller minskning av ljudnivån med 8-10 dBA brukar uppfattas som en fördubbling respektive halvering av ljudintrycket. En förändring med mindre än $3 \mathrm{dBA}$ är knappt uppfattbar. 



\section{Allmänt om täkter och deras miljöpåverkan}

Bergmaterialindustrin levererar material för att bygga vägar, järnvägar, i anläggnings- och bostadsbyggande samt för användning i vissa kemiska processer och inom miljövård. Råvaran är krossat berg, naturgrus. natursand, stenblock och återvunnet material.

Täktverksamhet sker huvudsakligen i öppna täkter. Brytning under jord är sällsynt men brytning kan ibland ske under grundvattennivån.

Bergmaterial och industrimineral utvinns med liknande produktionsmetoder.

Berget fragmenteras med hjälp av borrning och efterföljande sprängning. Materialet krossas sedan i flera steg för att slutligen siktas i olika fraktioner.

Blockstensindustrin utvinner så stora block som möjligt i ett stycke, ofta genom linsågning, för att sedan dela upp blocket till lämpliga delar. Sand- och grusindustrin tar ut material med lastmaskiner och lastar materialet för ev. krossning samt sortering där de olika fraktionerna skiljs från varandra.

\subsection{Täkter - Miljöfarlig verksamhet (Svenska förhållanden)}

Brytning och uttag av berg, naturgrus mm kan skapa miljöproblem eller orsaka skador på känsliga naturmiljöer. Innan man kan påbörja utvinning i täkten, måste man ha tillstånd enligt miljöbalken.

Täkter är tillståndspliktiga enligt 9 kap miljöbalken (miljöfarlig verksamhet). Täkter kan också prövas enligt andra delar som 11 kap (vattenverksamhet) eller 7 kap miljöbalken (områdesskydd).

Buller är en av de största miljöfrågorna för en bergtäktsverksamhet. I samband med en tillståndsansökan kräver oftast tillståndsmyndigheten att en bullerutredning utförs som en del av en miljökonsekvensbeskrivning ifall bostäder eller annan bebyggelse finns inom nära avstånd till den planerade verksamheten. 
Naturvårdsverket utarbetar föreskrifter, riktlinjer och Allmänna råd för buller. Länsstyrelserna hanterar tillståndsprövning och tillsyn av täkter. Tillsyn kan överlåtas till kommuner.

Miljöprövningsdelegationen lämnar tillstånd efter beredning på tillståndsmyndigheten (Länsstyrelse). En tillståndsansökan är skriftlig och innehåller ritningar och andra uppgifter om verksamhetens omfattning och dess miljökonsekvenser. Länsstyrelsens beslut kan överklagas för att avgöras i högre instans, detta gör att det ofta kan ta flera år att få tillstånd till en täktverksamhet. Tillståndet är oftast tidsbegränsat och förenat med villkor om hur täktverksamheten ska bedrivas.

\subsection{Vanliga drifttider hos bergtäkter i Sverige}

Vanliga drifttider vid en bergtäktsverksamhet är vardagar mellan kl. 06:00 och kl. 18:00. Inom en bergtäkt brukar vanligtvis enbart utlastning pågå mellan kl. 06-07. Övrig verksamhet startar i regel från kl. 07:00. Detta beror bland annat på att utlastning av bergmaterial till lastbil planeras till att kunna betjäna bygg- och anläggningsarbetsplatser tidigt samt att bullervillkoret dagtid (kl. 07:00-18:00) vid bostad är $50 \mathrm{dBA}$ jämfört nattkravet (kl. 22-07) som är $40 \mathrm{dBA}$, se tabell 1. 


\section{Riktvärden för buller i de nordiska länderna}

\subsection{Riktvärden för externt industribuller i Sverige}

För tillståndsansökan tillämpas normalt riktvärdesnivåerna för nyetablerad industri enligt Naturvårdsverkets råd och riktlinjer RR 1978:5. Följande riktvärden gäller enligt grundtabellen 2.1 (nyetablering av industri):

\begin{tabular}{|c|c|c|c|c|}
\hline \multirow[t]{2}{*}{ Områdesanvändning ${ }^{1)}$} & \multicolumn{3}{|c|}{ Ekvivalent ljudnivå i dBA } & \multirow{2}{*}{$\begin{array}{l}\text { Högsta ljudnivå i } \\
\text { dBA-läge "FAST" } \\
\text { Momentana } \\
\text { ljud nattetid } \\
\text { kl. 22-07 }\end{array}$} \\
\hline & $\begin{array}{r}\text { Dag } \\
\text { kl. 07-18 }\end{array}$ & $\begin{array}{r}\text { Kväll } \\
\text { KI. 18-22 } \\
\text { samt söndag } \\
\text { och helgdag } \\
\text { kl. 07-18 }\end{array}$ & $\begin{array}{r}\text { Natt } \\
\text { kl. } 22-07\end{array}$ & \\
\hline Arbetslokaler för ej bullrande verksamhet. & 60 & 55 & 50 & - \\
\hline $\begin{array}{l}\text { Bostäder och rekreationsytor i bostäders } \\
\text { grannskap samt utbildningslokaler och } \\
\text { vårdbyggnader. }\end{array}$ & 50 & 45 & $40^{2)}$ & 55 \\
\hline $\begin{array}{l}\text { Områden för fritidsbebyggelse och } \\
\text { rörligt friluftsliv där naturupplevelsen är } \\
\text { en viktig faktor. }{ }^{3)}\end{array}$ & 40 & 35 & 35 & 50 \\
\hline
\end{tabular}

${ }^{1)}$ Vid de fall kringliggande område ej utgörs av angivna områdestyper bör bullervillkoren anges på annat sätt, till exempel ljudnivå vid stadsplanegräns eller på ett visst avstånd från anläggningen. ${ }^{2)}$ Värdet för natt behöver inte tillämpas för utbildningslokaler.

${ }^{3)}$ Avser områden som planlagts för fritidsbebyggelse och rörligt friluftsliv.

Buller från lastbilstransporter klassas som externt industribuller inom ett industriområde. Tunga transporter på täktvägar påverkar hus nära vägen, även långt från täkten, och hanteras som en följdverksamhet. Täkttransporter klassas som externt industribuller fram till anslutningspunkt vid det allmänna vägnätet. Angående buller från transporter utanför verksamhetsområdet skall det, enligt Naturvårdsverkets allmänna råd, bedömas utgående från gällande riktvärden för vägtrafikbuller.

Enligt Externt industribuller - allmänna råd (SNV RR 1978:5 rev 1983) skärps kraven med 5 dBA om ljudet från en verksamhet innehåller: 
- ofta återkommande impulser såsom vid nitningsarbete, slag i transportörer, lossning av järnskrot etc.

- hörbara tonkomponenter

- bådadera ovanstående

\subsection{Riktvärden för externt industribuller i Norge}

Riktvärden för externt industribuller återfinns i: "FOR 2004-06-01 nr 931: Forskrift om begrensning av forurensning (forurensningsforskriften)." Buller från bergtäkter berörs av följande delar i föreskrifterna: støy for pukkverk § 30-7, asfaltverk § 24-8 og skipsverft § 29-7. För samtliga delar gäller riktvärden enligt tabell 2 .

For annen industri blir riktværden nedan som oftest også lagt til grunn når det gis en tillatelse til forurensning hjemlet i forurensningsloven.

Bedriftens bidrag til utendørs støy ved omkringliggende boliger, sykehus, pleieinstitusjoner, fritidsboliger, utdanningsinstitusjoner og barnehager skal ikke overskride følgende grenser, målt eller beregnet som frittfeltsverdi ved mest støyutsatte fasade:

Tabell 2. Riktvärden för externt industribuller i Norge

\begin{tabular}{llllll}
\hline $\begin{array}{l}\text { Mandag- } \\
\text { fredag }\end{array}$ & $\begin{array}{l}\text { Kveld mandag- } \\
\text { fredag }\end{array}$ & Lørdag & $\begin{array}{l}\text { Søn- } \\
\text { /helligdager }\end{array}$ & $\begin{array}{l}\text { Natt } \\
\mathbf{( k l . ~ 2 3 - 0 7 ) ~}\end{array}$ & $\begin{array}{l}\text { Natt } \\
\text { (kl. 23-07) }\end{array}$ \\
\hline $55 \mathrm{~L}_{\text {den }}$ & $50 \mathrm{~L}_{\text {evening }}$ & $50 \mathrm{~L}_{\text {den }}$ & $45 \mathrm{~L}_{\text {den }}$ & $45 \mathrm{~L}_{\text {night }}$ & $60 \mathrm{~L}_{\text {AFmax }}$ \\
\hline
\end{tabular}

$L_{\text {den }}$ er definert som døgnmiddel. Med impulsstøy eller rentonelyd er grensen 5 dBA lavere. Den strengeste grenseverdien legges til grunn når impulslyd opptrer med i gjennomsnitt mer enn 10 hendelser pr. time.

- Levening er A-veiet ekvivalentnivå for 4 timers kveldsperiode fra kl. 19-23.

- $\quad \mathrm{L}_{\text {night }}$ er A-veiet ekvivalentnivå for 8 timers nattperiode fra kl. 23-07.

- L Lafmax, er gjennomsnitt av de 5-10 høyeste forekommende støynivåene $L_{A F}$ (A-veid støynivå med Fast respons) fra en industribedrift i nattperioden 23-07.

Med impulslyd menes kortvarige, støtvise lydtrykk med varighet på under 1 sekund og der impulslyden er av typen "highly impulsive sound" som definert i T-1442 kapittel 6. Dersom impulslyd forekommer mer enn 10 hendelser per time er grenseverdien 5 dBA lavere enn de grenseverdier som er angitt i tabellen. 
Støygrensene gielder all støy fra bedriftens ordinære virksomhet, inkludert intern transport på bedriftsområdet og lossing/lasting av råvarer og produkter. Støy fra bygg- og anleggsvirksomhet og fra ordinær persontransport av virksomhetens ansatte er likevel ikke omfattet av grensene.

Støygrensene gjelder ikke for bebyggelse av forannevnte type som blir etablert etter at virksomheten har startet opp.

\subsection{Riktvärden för externt industribuller i Danmark}

Riktvärden för externt industribuller i Danmark beskrivs i "Miljøstyrelsens vejledning nr. 5/1984 Ekstern støj fra virksomheder." Tabell 3 nedan visar riktvärden för olika områden för dag-, kväll och nattperioder.

\begin{tabular}{|c|c|c|c|}
\hline \multirow[t]{2}{*}{ Område type } & \multicolumn{3}{|c|}{ Tidsrum } \\
\hline & $\begin{array}{r}\text { Mandag-Fredag } \\
\text { kl. 07-18, } \\
\text { lørdag kl. 07-14 }\end{array}$ & $\begin{array}{r}\text { Mandag-Fredag } \\
\text { kl. 18-22, lørdag } \\
\text { kl. 14-22, søn- og } \\
\text { helligdage kl. 07-22 }\end{array}$ & $\begin{array}{l}\text { Alle dage } \\
\text { kl. 07-22 }\end{array}$ \\
\hline 1 Erhvervs- og industriområde & 70 & 70 & 70 \\
\hline $\begin{array}{l}2 \text { Erhvervs- og industriområde med forbud } \\
\text { mod generende virksomheder }\end{array}$ & 60 & 60 & 60 \\
\hline $\begin{array}{l}3 \text { Områder for blandet bolig- og erhvervs- } \\
\text { bebyggelse, centerområder (bykerne) }\end{array}$ & 55 & 45 & 40 \\
\hline 4 Etageboligområder & 50 & 45 & 40 \\
\hline 5 Boligområder for åben og lav bebyggelse & 45 & 40 & 35 \\
\hline $\begin{array}{l}6 \text { Sommerhusområder og offentligt tilgæn- } \\
\text { gelige rekreative områder }\end{array}$ & 40 & 35 & 35 \\
\hline
\end{tabular}

Riktvärden anges som A-vägda ekvivalenta korrigerade ljudnivåer. Den ekvivalenta ljudnivån är ljudets medelvärde över en längre tidsperiod (dagtid 8 timmar, kvällstid 1 timme och nattetid 0,5 timme). Om ljudet innehåller tydligt hörbara toner eller impulser skall man addera $5 \mathrm{~dB}$ till den ekvivalenta ljudnivån för att bestämma bullerbelastningen.

Bullergränserna i ett bullervillkor skall innehållas i alla punkter utomhus i det berörda området, alltså inte bara i närhet av byggnader.

För områden med bostäder finns ytterligare ett riktvärde avseende momentana maximala ljudnivåer nattetid $\mathrm{L}_{\mathrm{AFmax}}$. Riktvärdet för momentan maximal ljudnivå är 50 eller 55 dBA. 


\subsection{Riktvärden för externt industribuller på Färöarna}

Färöarna har traditionellt använt sig av Danmarks bedömningsgrunder avseende externt industribuller.

Tabell 4. Riktvärden för externt industribuller på Färöarna, ljudtrycksnivå i dBA

\begin{tabular}{|c|c|c|c|}
\hline \multirow[t]{2}{*}{ Område type } & \multicolumn{3}{|c|}{ Tidsrum } \\
\hline & $\begin{array}{r}\text { Mandag-Fredag } \\
\text { kl. 07-18, Iørdag } \\
\text { kl. 07-14 }\end{array}$ & $\begin{array}{r}\text { Mandag-Fredag } \\
\text { kl. 18-22, lørdag } \\
\text { kl. 14-22, søn- og } \\
\text { helligdage kl. 07-22 }\end{array}$ & $\begin{array}{l}\text { Alle dage } \\
\text { kl. 07-22 }\end{array}$ \\
\hline 1 Erhvervs- og industriområde & 70 & 70 & 70 \\
\hline $\begin{array}{l}2 \text { Erhvervs- og industriområde med forbud } \\
\text { mod generende virksomheder }\end{array}$ & 60 & 60 & 60 \\
\hline $\begin{array}{l}3 \text { Områder for blandet bolig- og erhvervs- } \\
\text { bebyggelse, centerområder (bykerne) }\end{array}$ & 55 & 45 & 40 \\
\hline 5 Boligområder for åben og lav bebyggelse & 45 & 40 & 35 \\
\hline
\end{tabular}

\subsection{Riktvärden för externt industribuller i Finland}

Beslut av statsrådet med stöd av $9 \S$ bullerbekämpningslagen den 3 april 1987 (382/87) vid föredragning från miljöministeriet.

Tabell 5. Riktvärden för externt industribuller i Finland

\begin{tabular}{|c|c|c|}
\hline \multirow[t]{2}{*}{ Områdesanvändning } & \multicolumn{2}{|c|}{ Ekvivalent ljudnivå i dBA } \\
\hline & Dag kl. 07-22 & Natt kl. 22-07 \\
\hline $\begin{array}{l}\text { I bostadsområden, rekreationsområden i tätorter } \\
\text { eller i deras omedelbara närhet och i områden } \\
\text { avsedda för vårdinrättningar eller läroanstalter }\end{array}$ & 55 & $50 / 45^{1)}$ \\
\hline $\begin{array}{l}\text { I områden med fritidshus }{ }^{2} \text {, } \text {, campingområden, } \\
\text { rekreationsområden utanför tätorterna och i } \\
\text { naturskyddsområden }\end{array}$ & 45 & $40^{3)}$ \\
\hline \multicolumn{3}{|c|}{ 1) I nya bostadsområden tillämpas emellertid riktvärdet $45 \mathrm{~dB}$ nattetid. Nattriktvärdena tillämpas } \\
\hline
\end{tabular}

Om bullret till sin natur är slagartat eller smalbandigt, adderas $5 \mathrm{~dB}$ till mätnings- eller beräkningsresultatet innan det jämförs med det riktvärdet enligt tabell 5 . 


\subsection{Riktvärden för externt industribuller på Åland}

Samtliga utomhusvärden avser frifältsvärde (opåverkade av reflexer i näraliggande fasad) om inget annat anges. Riktvärdena är en utgångspunkt och vägledning för den bedömning, som görs i varje enskilt fall. Särskilda skäl kan medföra att avsteg kan behöva göras, såväl uppåt som nedåt, från de angivna riktvärdena.

Tabell 6. Riktvärden för externt industribuller på Åland

\begin{tabular}{llll}
\hline \multirow{2}{*}{ Områdesanvändning } & \multicolumn{3}{c}{ Ekvivalent ljudnivå i dBA } \\
\cline { 2 - 4 } & $\begin{array}{l}\text { Dagtid (kl 07-18) helgfri } \\
\text { måndag till fredag }\end{array}$ & $\begin{array}{l}\text { Kvällstid (kl 18-22) } \\
\text { samt lördag, söndag } \\
\text { och helgdag (kl. 07-18) }\end{array}$ & $\begin{array}{l}\text { Nattetid } \\
\text { (kl 22-07) }\end{array}$ \\
\hline $\begin{array}{l}\text { Permanent- eller fritidsbostad, } \\
\text { samlingslokal, vårdinrättningar eller } \\
\text { liknande verksamhet }\end{array}$ & 50 & 45 & 40 \\
\hline
\end{tabular}

\subsection{Riktvärden för externt industribuller på Island}

Tabell 7. Riktvärden för externt industribuller på Island, ljudtrycksnivå i dBA

\begin{tabular}{|c|c|c|c|c|c|c|c|}
\hline \multirow[t]{3}{*}{ Typ av fastighet } & \multicolumn{7}{|c|}{ Gränser för företagsverksamhet } \\
\hline & \multicolumn{2}{|c|}{$L A_{e q}(07-19)$} & \multicolumn{2}{|c|}{$L A_{e q}(19-23)$} & \multicolumn{2}{|c|}{$\mathrm{LA}_{\mathrm{eq}}(23-07)$} & \multirow{2}{*}{$\begin{array}{l}\mathrm{L}_{\mathrm{AFmax}} \\
\text { natt } \\
\begin{array}{r}\text { Inom } \\
\text { hus }\end{array}\end{array}$} \\
\hline & $\begin{array}{r}\text { Vid } \\
\text { fasad }\end{array}$ & $\begin{array}{l}\text { Inom- } \\
\text { hus }\end{array}$ & $\begin{array}{r}\text { Vid } \\
\text { fasad }\end{array}$ & $\begin{array}{l}\text { Inom- } \\
\text { hus }\end{array}$ & $\begin{array}{r}\text { Vid } \\
\text { fasad }\end{array}$ & $\begin{array}{l}\text { Inom- } \\
\text { hus }\end{array}$ & \\
\hline Privata bostäder i bostadsområde & 50 & 30 & 45 & 30 & 40 & 25 & 40 \\
\hline Bostäder i butiksområden & 55 & 30 & 55 & 30 & 40 & 30 & 45 \\
\hline $\begin{array}{l}\text { Samlingsutrymmen hos vård och äldre- } \\
\text { omsorg där boende/intagna vistas under } \\
\text { längre perioder }\end{array}$ & $60^{*}$ & 35 & $50 *$ & 35 & $50 *$ & 30 & 45 \\
\hline Industriområden och hamnar & 70 & & 70 & & 70 & & \\
\hline Fritidsbebyggelser & 35 & & 35 & & 35 & & 35 \\
\hline För- och Grundskola & $50 *$ & 30 & & & & & \\
\hline Undervisningslokaler i Gymnasieskola & & 30 & & & & & \\
\hline $\begin{array}{l}\text { Ej bullriga arbetsplatser. Kontor och } \\
\text { liknande }\end{array}$ & & 30 & & & & & \\
\hline
\end{tabular}

*Bullernivåer vid fasad får vara högre om bullerdämpade friskluftsintag i fasad används. 


\subsection{Jämförelse av riktvärden för externt industribuller i de nordiska länderna}

Sverige, Åland och Island har mycket liknande riktvärden, ( $\mathrm{L}_{\text {Aeq }}$ dag/kväll/natt 50/45/40).

Norge har genomgående $5 \mathrm{dBA}$ högre riktvärden men använder Avägd $L_{d e n}$ istället för $A$-vägd Leq. Finland har också genomgående $5 \mathrm{dBA}$ högre riktvärden än Sverige m.fl. och har förlängt dagtiden till kl. 07-22.

Danmark har upp till fyra olika kategorier för bostäder där riktvärdena varierar från ( $\mathrm{L}_{\text {Aeq }} \mathrm{dag} / \mathrm{kväll} /$ natt $55 / 50 / 45$ ) till ( $\mathrm{L}_{\text {Aeq }} \mathrm{dag} / \mathrm{kväll} /$ natt 40/35/35). Färöarnas riktvärden överenstämmer i stort med Danmarks.

Krav på maximal ljudnivå finns i de svenska och norska riktvärdena.

Norge har en tydligt beskriven förklaring av vad man avser med ofta återkommande impulsljud, vilket t.ex de svenska riktvärdena saknar. 


\section{Bullerbekämpning allmänt}

Generellt kan man indela bullerbekämpning av industribullerkällor i tre delar:

1. Minska bullret vid källan.

2. Förhindra bullerspridning längs utbredningsvägen.

3. Minska bullret vid mottagaren.

Indelningen av vilka åtgärder som är tillämpbara beror oftast på vilket stadie den bullrande verksamheten är i, samt vilket behov av bullerdämpning som finns. Allmänt kan sägas att de tre punkterna ovan är redovisade i prioritetsordning. Det är oftast mest effektivt att åtgärda källan.

\subsection{Minska buller vid källan}

Att bulleråtgärda källan ger effekt för samtliga utbredningsriktningar och bergtäktverksamheten får en större frihet i sitt arbete och behöver inte fokusera på att bygga upp och jobba bakom t.ex. bullervallar etc. för att innehålla bullervillkor till omgivningen. Att åtgärda vid källan skapar också bättre ljudmiljö vid arbetsplatserna för den personal som hanterar borrigg, grävmaskin och övriga maskiner i täkten.

Typiska principåtgärder för att dämpa buller vid källan är:

- Val av tystare maskin.

- Val av arbetsmetod.

- Påverka störkrafter, göra processen "mjukare" med kortare fallhöjder etc.

- Minska ljudutstrålning från vibrerande ytor.

- Kontinuerligt underhåll 


\subsection{Förhindra bullerspridning längs utbredningsvägen}

Att minska bullerutbredningen mellan källa och mottagare är ofta den mest tillämpbara metoden i samband med befintliga bergtäkter.

Figur 2. Principskiss bullerdämpning med vall nära bullerkälla

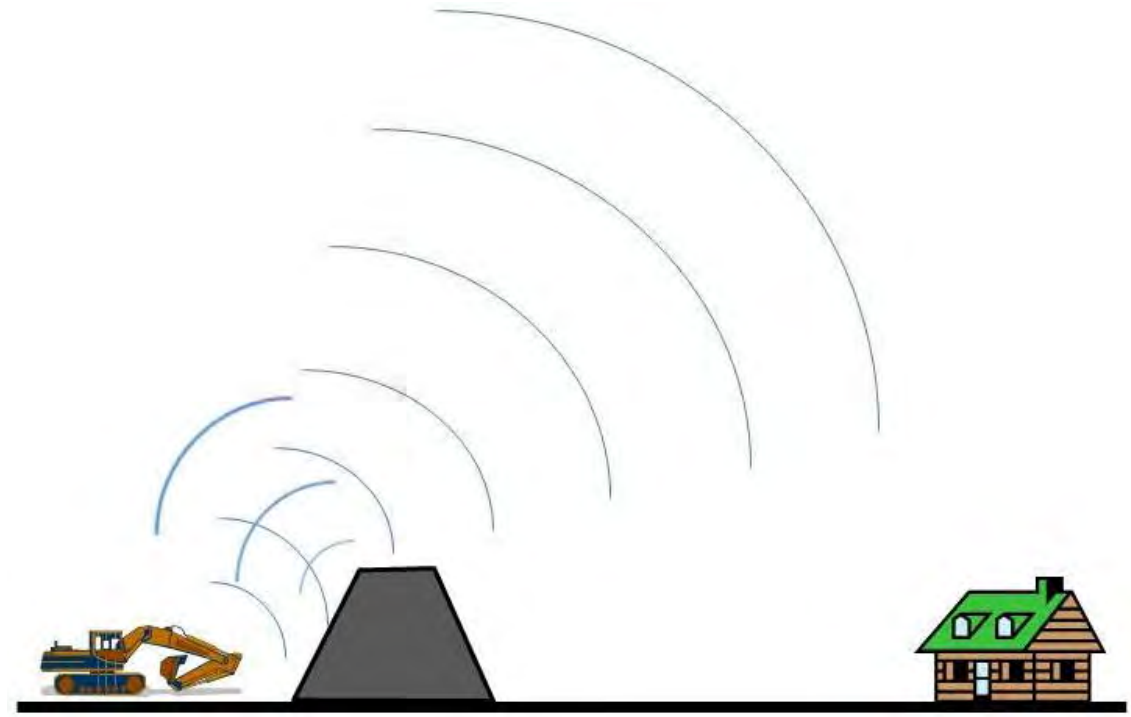

Typiska principåtgärder är:

- Inbyggnader, t.ex. av kompressorer och krossar.

- Avskärmning genom uppbyggda bullervallar.

- Avskärmning genom lokala, mobila skärmar.

- Placering av maskiner invid naturlig och skapad topografi för att medge skärmeffekt. Med skapad topografi menas t.ex. upplag av jordoch bergmaterial samt täktkanter.

- Att välja en brytriktning som medger bulleravskärmning mot berörda områden.

\subsection{Minska buller vid mottagaren}

Att reducera ljudet enbart vid mottagare kan ofta bli kostsamt om det är flera mottagare som berörs av denna typ av åtgärd kring en bergtäktsverksamhet.

Typiska principåtgärder är: 
- Avskärmning nära fastighetsgräns genom uppbyggda bullervallar.

- Avskärmning av buller från transporter med hjälp av plank och/eller bullervall.

Figur 3. Principskiss bullerdämpning med bullerplank nära mottagare

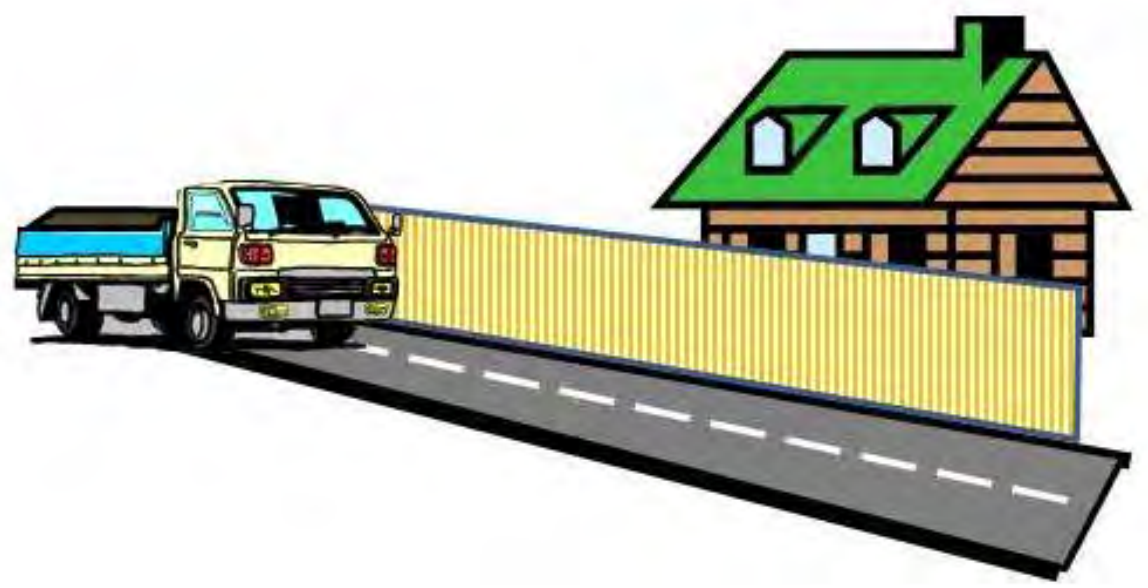





\section{Bullerbekämpning i bergtäkter}

Inom bergtäktsverksamhet arbetar man med bullerfrågan både för att minska buller till omgivningen men även för att minska buller i arbetsmiljön för de anställda.

Inom täktverksamheter har man ofta en god förståelse för hur buller sprids och kan dämpas till omgivningen. Placering av bullriga maskiner i bullerskyddade lägen t.ex. invid en täktkant, något som ofta används. Kompressorer byggs ofta in i skjul. Materialupplag placeras vanligtvis i den riktning där närliggande bostäder eller annan bebyggelse återfinns. Morän och reststen klassas inte som avfall om det kan användas som t.ex. bullervallar. I samband med avbaning av ett jordlager för att nå ner till bergytan jobbar man aktivt med att skapa bullervallar av detta överskottsmaterial. Den typen av bullervall används ofta vid bergborrning.

Vanliga misstag som görs vad gäller bullerfrågor och som kan uppröra boende i omgivningen är att man inte respekterar tider och inte informerar sina grannar om förändringar i verksamheten. Klagomål brukar ofta handla om att transporter dammar, lastbilarna upplevs köra för fort och att bulleremissionen från täkten upplevs olika vid olika väderförhållanden som kan leda till att buller uppmärksammas. Drift sommardagar kan störa boende som har semester och som boende som normalt inte vistas i området t.ex. sommarboende.

Flera täkter jobbar aktivt med bullerfrågor genom att informera grannar om sin verksamhet med s.k. "öppen täkt," och utskick med information. Att bjuda in till "öppen täkt" där verksamheten visas för allmänheten under avspända former kan skapa en bra grogrund för samarbete och förståelse mellan verksamheten och dess grannar. Information är mycket viktigt när det gäller buller för att skapa en ökad tolerans, exempelvis när täkten måste drivas maximalt under en kort kampanjperiod. Checklista till bergtäkter för att minimera bullerstörning 
Tabell 5. Checklista bullerdämpande åtgärder

\begin{tabular}{|c|c|c|}
\hline Aktivitet & Maskin & Rekommenderad åtgärd/utförande/planering \\
\hline Borrning & Bergborrmaskin & $\begin{array}{l}\text { Använd dämpad borrigg och/eller bullervallar/bullerskärm i } \\
\text { samband med borrning högt på ytberget. }\end{array}$ \\
\hline $\begin{array}{l}\text { Skutknack- } \\
\text { ning }\end{array}$ & $\begin{array}{l}\text { Grävmaskin med hy- } \\
\text { draulhammare }\end{array}$ & $\begin{array}{l}\text { Skutknackning utförs vid salvan och bör minimeras genom } \\
\text { arbete i om möjligt avskärmade lägen samt i relativt korta } \\
\text { tidsperioder. }\end{array}$ \\
\hline $\begin{array}{l}\text { Krossning } \\
\text { och siktning }\end{array}$ & $\begin{array}{l}\text { Förkross, efterkross, } \\
\text { kompressor, sorterings- } \\
\text { verk, grävmaskin, hjullas- } \\
\text { tare och transportband. }\end{array}$ & $\begin{array}{l}\text { Krossplats bör placeras så nära täktkant som möjligt i den till } \\
\text { omgivningen känsligaste riktningen. Upplagshögar läggs upp } \\
\text { så att de utgör bulleravskärmning från sorteringsverk och } \\
\text { krossverk. } \\
\text { Inbyggnad av kompressor. }\end{array}$ \\
\hline Utlastning & Hjullastare och lastbilar & $\begin{array}{l}\text { Utlastning utförs om möjligt i bullerskyddat läge från upplags- } \\
\text { högar av grus och sand. } \\
\text { Lastbilar kan med fördel förses med gummiinklädda flak för } \\
\text { att minska buller. }\end{array}$ \\
\hline Transporter & Lastbil & $\begin{array}{l}\text { Transportvägar kan med fördel asfaltbeläggas. Detta minskar } \\
\text { buller och damning till närboende. Hastigheten på täktvägen } \\
\text { bör begränsas till ca } 30-50 \mathrm{~km} / \mathrm{h} \text { nära bostäder. }\end{array}$ \\
\hline $\begin{array}{l}\text { Information } \\
\text { till närboen- } \\
\text { de }\end{array}$ & $\begin{array}{l}\text { Speciella händelser, t.ex. } \\
\text { sprängning, tillfällig } \\
\text { kampanjverksamhet }\end{array}$ & $\begin{array}{l}\text { Att informera grannar om tider för sprängning och andra } \\
\text { speciella händelser i verksamheten är viktigt för att öka } \\
\text { toleransen till bergtäkten. }\end{array}$ \\
\hline
\end{tabular}




\section{Bullerkällor i täktverksamhet}

Leverantörer av maskinell utrustning till bergtäkter har kontaktats angående uppmätt ljuddata på deras produkter. Produkter där ljuddata finns tillgängligt redovisas. Flertalet mätdata redovisas enligt EUdirektivet 2000/14/EC eller mätstandarden ISO 6395 (ISO 6395:2008 Anläggningsmaskiner - Bestämning av ljudeffektnivå - Provning av maskin $i$ arbete).

EU-direktivet 2000/14/EC kräver att maskiner, tillhörande 57 olika typer av utomhusutrustning, ska vara märkta med den garanterade Avägda ljudeffektnivån. Direktivet ingår i svensk lag genom förordning 2001:1084.

\subsection{Borriggar}

Topp- och sänkhammarborrning är de vanligast förekommande borrningsmetoderna i bergtäkter. I det förstnämnda fallet sitter borrhammaren uppe över markplanet och i det senare fallet är den placerad nere i borrhålet. Buller genereras främst från borrstål och borrigg men även från kompressor, luftintag och ljudutstrålning från ytor.

\section{Figur 4. Exempel på borriggar}
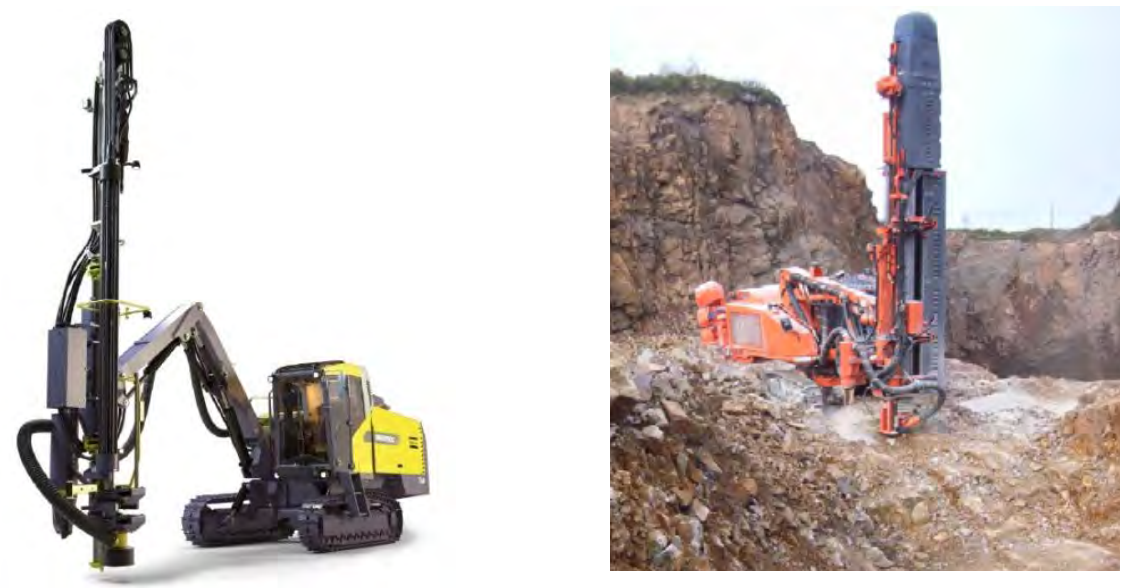

Källa: Atlas Copco. Till vänster Atlas Copco PowerRoc T3. Sandvik. Till höger Sandvik DX780 med monterat "Noiseguard muffler system." 
Tabell 6. Ljudeffektnivå Borriggar avsedda för bl.a. borrning i bergtäkter

\begin{tabular}{llll}
\hline Leverantör & Modell & Typ & Ljudeffektnivå LwA, dBA \\
\hline Atlas Copco & FlexiRoc D50 & Sänkhammare & 128 \\
Atlas Copco & FlexiRoc D55 & Sänkhammare & 128 \\
Atlas Copco & FlexiRoc T50 & Topphammare & 130 \\
Atlas Copco & PowerRoc T25 & Topphammare & 121 \\
Atlas Copco & PowerRoc T30 & Topphammare & 121 \\
Atlas Copco & PowerRoc T35 & Topphammare & 124 \\
Atlas Copco & SmartRoc T35 & Topphammare & 127 \\
Atlas Copco & SmartRoc T40 & Topphammare & 127 \\
Sandvik & DX 680 & Topphammare & 124 \\
\hline
\end{tabular}

\section{Möjligheter till bullerdämpning:}

Tillverkarna Atlas Copco samt Sandvik har tagit fram ljuddämpande borriggar för topphammarriggar som i bådas fall går ut på att kapsla in borrstativet samt dämpa luftintag och utlopp. För dessa båda tillverkare säljs bullerdämpningen som ett tillbehör/option som går att tillämpa på flera av dessa leverantörers borriggar. Bullerreduceringen till omgivningen anges av båda tillverkarna till ca $10 \mathrm{dBA}$ jämfört motsvarande borrigg i odämpat utförande. Sandviks ljuddämpade borrigg visas i figur 4, Atlas Copcos motsvarighet kallas för Atlas Copco Silenced Smartrig.

Ytterligare en fördel med att ljuddämpa borriggen är att ljudnivån på operatörsplats i hytt sänks avsevärt.

\subsection{Bergkrossar}

Vid krossning omvandlas stenar och block till makadam med olika typer av krossmetoder. Vanliga typer av krossar är käftkrossar, slagkrossar, konkrossar och spindelkrossar. Förkrossning av stora fraktioner utförs ofta med käftkrossar och efterkrossning sker ofta med kon- eller spindelkross.

Man skiljer mellan stationära och mobila krossar. Stationära krossar används ofta i större täkter där material bärs med lastmaskiner till krossplatsen. Med mobila krossar kan krossningen utföras nära brytfronten vilket ger korta bärsträckor för lastmaskiner.

Buller genereras från lastning av bergmaterial och från den mekaniska bearbetningen av bergmaterialet. Ljud utstrålas både som luftburet och stomburet ljud. 
Figur 5. Metso Lokotrack LT 116, mobil käftkross

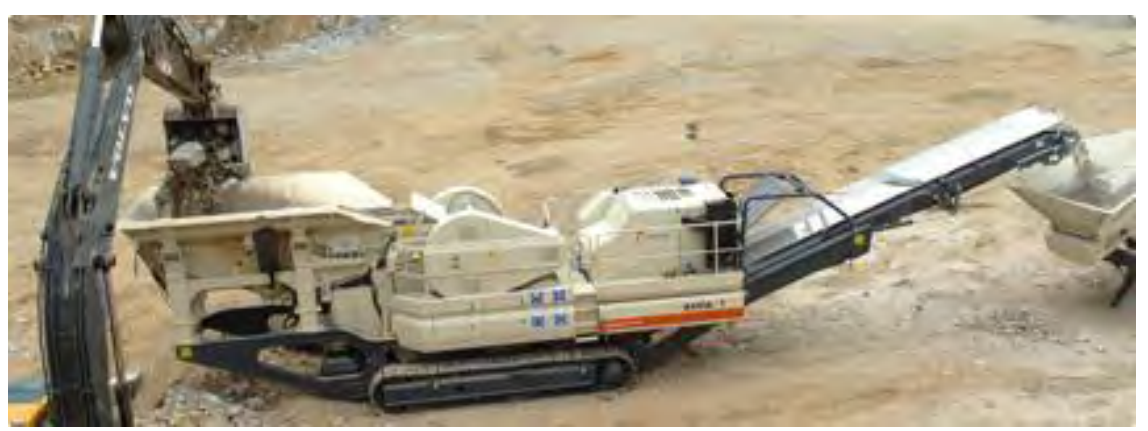

Källa: Metso

Av de tillverkare som kontrollerats har ingen kunnat tillhandahålla uppmätt ljuddata enligt t.ex. EU-direktivet 2000/14/EC. Stora leverantörer av krossutrustning är Atlas Copco, Metso och Sandvik. Uppmätta ljudeffektnivåer från bergkrossar redovisas i kapitel 8.

\section{Möjligheter till bullerdämpning:}

Det saknas redovisning av ljudemissionen från ljuddämpade krossar på marknaden. Vissa krossar saluförs med att de är förhållandevis tysta, men mått på ljuddämpningen redovisas inte. För att dämpa buller från krossar är det vanligt att avskärma verksamheten bakom skapad topografi i form av täktkanter, materialupplag och konstruerade bullervallar. Vid stationära krossar finns exempel på där krossningen helt eller delvis har byggts in med ljudisolerande byggnadselement.

\subsection{Sorteringsverk}

Sorteringsverk siktar krossat bergmaterial eller naturgrus i olika fraktioner. Krossat bergmaterial läggs på en sikt som med minskande öppningsstorlek på sina olika siktgaller fördelar materialet i olika storlekar genom sikten med hjälp av skakning. Det siktade materialet leds vidare till upplagshögar med hjälp av transportörer.

Man skiljer mellan stationära och mobila sorteringsverk på samma sätt som för bergkrossar.

Buller genereras från skakningen av materialet genom siktarna och från lastning av bergmaterial. Ljud utstrålas både som luftburet och stomburet ljud. 


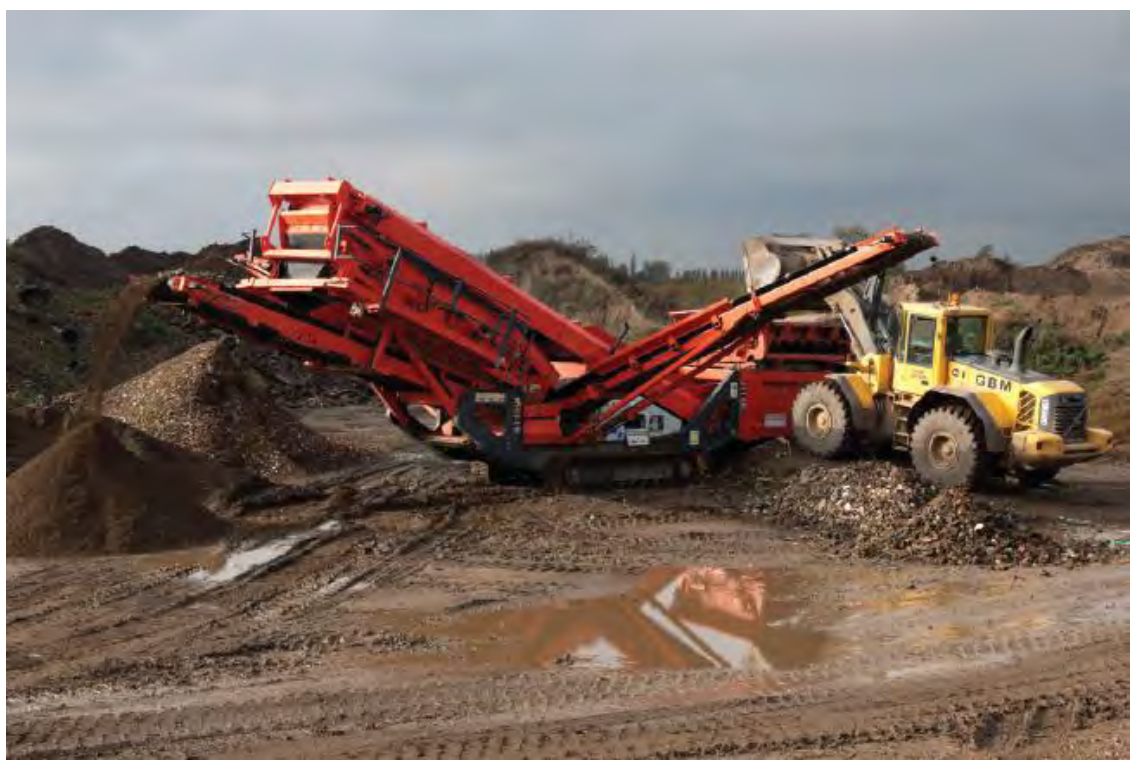

Källa: Sandvik.

Av de tillverkare som kontrollerats har ingen kunnat tillhandahålla uppmätt ljuddata enligt t.ex. EU-direktivet 2000/14/EC. Stora leverantörer av sorteringsverk är Atlas Copco, Metso och Sandvik. Uppmätta ljudeffektnivåer från sorteringsverk redovisas i kapitel 8.

\section{Möjligheter till bullerdämpning:}

Man kan dämpa buller som genereras vid den mekaniska skakningen av bergmaterial mot siktgaller genom att använda siktgaller av gummi eller som är gummibeklädda. Vanligtvis dämpas buller från siktar på samma sätt som för bergkrossar genom avskärmning till omgivningen via skapad topografi i form av täktkanter, materialupplag och konstruerade bullervallar. Vid större fasta anläggningar installeras skakmaskinerna i särskilda byggnader.

\subsection{Grävmaskiner}

Grävmaskiner används för flera ändamål i en bergtäkt. Grävmaskiner bryter loss utsprängt bergmaterial vid brytfronten och lastar till dumper i större bergtäkter. Grävmaskiner används ofta till att lasta förkrossen. Grävmaskiner används även i samband med skutknackning, se kapitel 8.5. 
Buller från grävmaskiner skapas vid hantering av sten när grävskopan fylls samt lastning till lastmaskin eller kross. Andra bullerkällor från grävmaskin är buller från t.ex. luftintag.

Figur 7. Exempel på bandgrävmaskin. Volvo EC 360 C

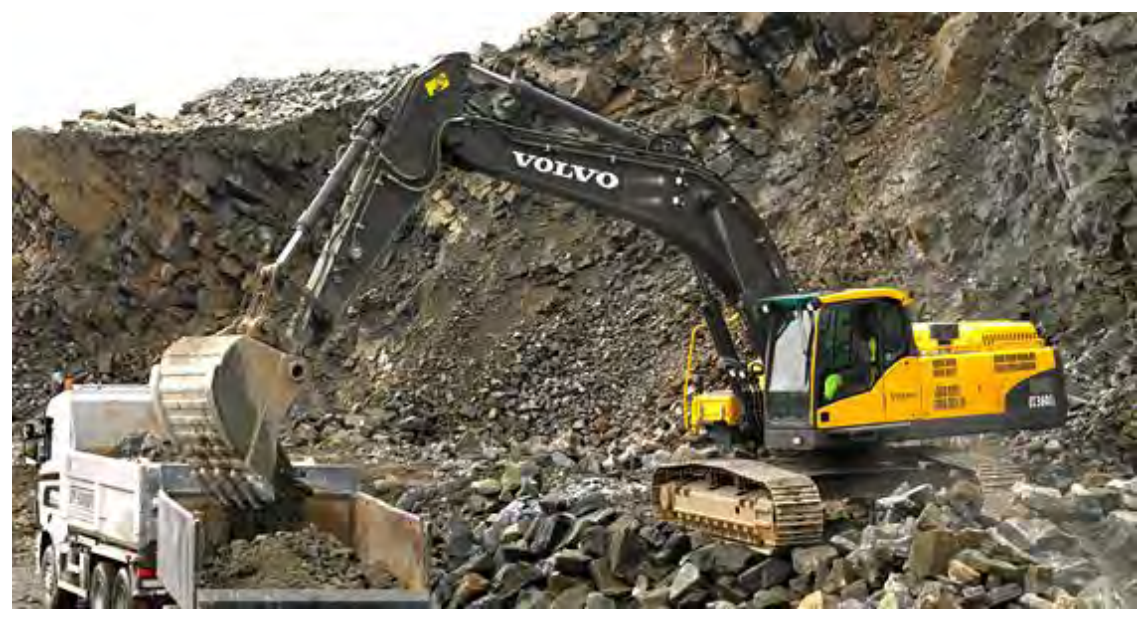

Källa: Volvo CE.

Tabell 7. Ljudeffektnivå Bandgrävmaskiner avsedda för bl.a. arbete i bergtäkter

\begin{tabular}{llll}
\hline Leverantör & Modell & Typ & Ljudeffektnivå L $\mathbf{w A}_{\mathbf{w}} \mathbf{d B A}$ \\
\hline Volvo CE & EC 700 C & Bandgrävmaskin & 107 \\
Volvo CE & EC 460 C & Bandgrävmaskin & 106 \\
Volvo CE & EC 480 D & Bandgrävmaskin & 106 \\
Volvo CE & EC 380 D & Bandgrävmaskin & 105 \\
Volvo CE & EC 360 C & Bandgrävmaskin & 105 \\
Volvo CE & EC 305 C & Bandgrävmaskin & 103 \\
Volvo CE & EC 300 D & Bandgrävmaskin & 104 \\
Volvo CE & EC 250 D & Bandgrävmaskin & 103 \\
Volvo CE & EC 220 D & Bandgrävmaskin & 102 \\
Caterpillar & 325 D L/LN & Bandgrävmaskin & 104 \\
Caterpillar & 323 E L/LN & Bandgrävmaskin & 103 \\
Caterpillar & 320 E L/LN/LRR & Bandgrävmaskin & 103 \\
Caterpillar & 323 D L/LN & Bandgrävmaskin & 102 \\
Caterpillar & $323 \mathrm{E} \mathrm{SA}$ & Bandgrävmaskin & 103 \\
Caterpillar & 324 E & Bandgrävmaskin & 104 \\
Caterpillar & $329 \mathrm{E}$ & Bandgrävmaskin & 105 \\
Komatsu & PC240 & Bandgrävmaskin & 103 \\
Komatsu & PC290 & Bandgrävmaskin & 104 \\
Komatsu & PC360 & Bandgrävmaskin & 105 \\
Komatsu & PC490 & Bandgrävmaskin & 107 \\
\hline
\end{tabular}

\section{Möjligheter till bullerdämpning:}

Bulleremissionen från grävmaskiner ökar i regel med större maskiner. Flera tillverkare satsar på att skapa en god arbetsmiljö i hytten men ingen tillverkare har på ett systematiskt sätt försökt att dämpa det externa bullret. Att dämpa det buller som uppstår i grävskopan vid hante- 
ringen av sten och lastning är dock svårt att komma åt. Lastflak hos lastbil/dumper kan dock förses med gummi vilket dämpar buller med ca 10 dBA jämfört utan gummibeklädnad. Man kan på samma sätt som med borriggar dämpa luftintag. Stora tillverkare är bl. a. Volvo CE, Caterpillar och Komatsu.

\subsection{Skutknackare}

I samband med sprängning erhålls ibland block eller skut ur sprängsalvan som är för stora för att kunna krossas. Skut uppkommer ofta på grund av att spränghålsborrningen har avvikit från sin tänkta bana och skapat stora avstånd borrhålen sinsemellan vilket ger ett större styckefall. Dessa block behöver delas ytterligare och denna delning görs med hjälp av en hydraulhammare kopplad till en grävmaskin. Buller från skutknackningen är ofta kraftigt och relativt högfrekvent till karaktären.

Figur 8. Exempel på hydraulhammare kopplad till grävmaskin

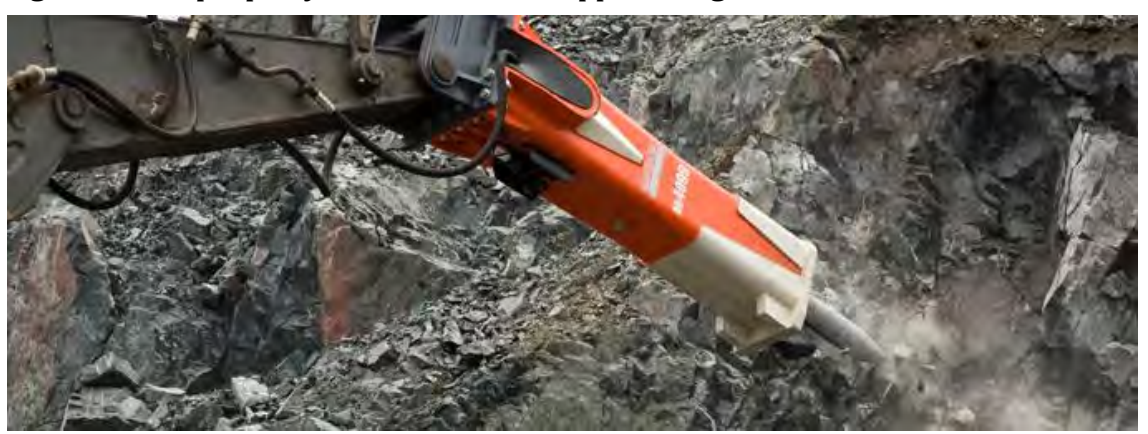

Källa: Sandvik.

\section{Möjligheter till bullerdämpning}

Ljudemissionen beror till stor del på storleken hos hammaren samt om hydraulhammaren är innesluten i en ljuddämpande konstruktion. Skutknackning utförs ofta under relativt korta tidsperioder på täktbotten.

Genom att studera vilken borrteknik (diameter hos borrstål, typ av borrkrona, rotationshastighet, etc.) som ger rakast hål kan borrhålsavvikelse minimeras och förutsättningar för ett optimalt styckefall skapas som minskar skutbildning och behov av skutknackning. 
Tabell 8. Ljudeffektnivå Hydraulhammare

\begin{tabular}{|c|c|c|c|}
\hline Leverantör & Modell & Typ & Ljudeffektnivå $L_{w A}, d B A$ \\
\hline Atlas Copco & HB $2000 / D P$ & Hydraulhammare & 120 \\
\hline Atlas Copco & HB $2500 / D P$ & Hydraulhammare & 121 \\
\hline Atlas Copco & MB $1000 / D P$ & Hydraulhammare & 119 \\
\hline Atlas Copco & $\mathrm{MB} 1000 \mathrm{E}$ & Hydraulhammare & 125 \\
\hline Atlas Copco & MB $1200 / D P$ & Hydraulhammare & 117 \\
\hline Atlas Copco & MB $1200 \mathrm{E}$ & Hydraulhammare & 121 \\
\hline Atlas Copco & MB $1500 / D P$ & Hydraulhammare & 120 \\
\hline Atlas Copco & $\mathrm{MB} 1500 \mathrm{E}$ & Hydraulhammare & 127 \\
\hline Atlas Copco & MB $1700 / D P$ & Hydraulhammare & 117 \\
\hline Atlas Copco & $\mathrm{MB} 1700 \mathrm{E}$ & Hydraulhammare & 123 \\
\hline Atlas Copco & MB $750 / D P$ & Hydraulhammare & 117 \\
\hline Atlas Copco & $\mathrm{MB} 750 \mathrm{E}$ & Hydraulhammare & 123 \\
\hline Atlas Copco & SB 702 & Hydraulhammare & 122 \\
\hline Soosan & SB 60 & Hydraulhammare & 115 \\
\hline Soosan & SB 70 & Hydraulhammare & 120 \\
\hline Soosan & SB 81 & Hydraulhammare & 118 \\
\hline Soosan & SB 100 & Hydraulhammare & 120 \\
\hline Soosan & SB 121 & Hydraulhammare & 123 \\
\hline Soosan & SB 130 & Hydraulhammare & 124 \\
\hline Soosan & SB 140 & Hydraulhammare & 124 \\
\hline Soosan & SB 151 & Hydraulhammare & 125 \\
\hline Sandvik & BR422 & Hydraulhammare & $128\left(118^{*}\right)$ \\
\hline Sandvik & BR623 & Hydraulhammare & $132(121 *)$ \\
\hline Sandvik & BR825 & Hydraulhammare & $134(125 *)$ \\
\hline Sandvik & BR927 & Hydraulhammare & $135\left(127^{*}\right)$ \\
\hline Sandvik & BR1229 & Hydraulhammare & $136\left(126^{*}\right)$ \\
\hline Sandvik & BR555 & Hydraulhammare & 129 \\
\hline Sandvik & BR777 & Hydraulhammare & 129 \\
\hline Sandvik & BR999 & Hydraulhammare & 127 \\
\hline Sandvik & BR2155 & Hydraulhammare & 128 \\
\hline Sandvik & BR2577 & Hydraulhammare & 124 \\
\hline Sandvik & BR3288 & Hydraulhammare & 124 \\
\hline Sandvik & BR4099 & Hydraulhammare & 130 \\
\hline
\end{tabular}

*Produkter marknadsförs som "bullerdämpade"

\subsection{Dumpers}

I större bergtäkter där man har behov av att transportera material längre sträckor t.ex. mellan brytfront och krossplats används ofta dumpers. Buller från drivning och i samband med lastning och tippning är viktiga bullerkällor. 
Figur 9. Ramstyrd dumper av märket Caterpillar 725.

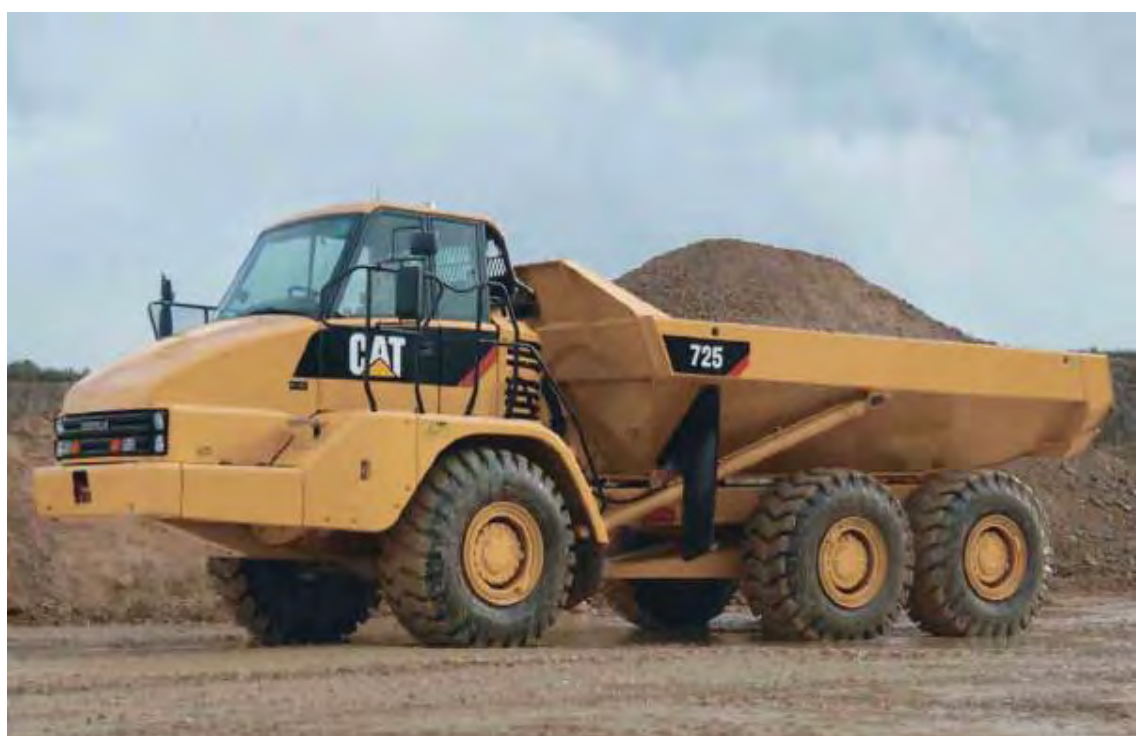

Källa: Caterpillar.

Tabell 9. Ljudeffektnivå Dumpers

\begin{tabular}{llll}
\hline Leverantör & Modell & Typ & Ljudeffektnivå $\mathrm{L}_{\text {wA }}$, dBA \\
\hline Caterpillar & 725 & Ramstyrd dumper & 111 \\
Caterpillar & 730 & Ramstyrd dumper & 111 \\
Volvo CE & $\mathrm{A} 25 \mathrm{~F}$ & Ramstyrd dumper & 108 \\
Volvo CE & $\mathrm{A} 30 \mathrm{~F}$ & Ramstyrd dumper & 109 \\
Volvo CE & $\mathrm{A} 35 \mathrm{~F}$ & Ramstyrd dumper & 110 \\
Volvo CE & $\mathrm{A} 40 \mathrm{~F}$ & Ramstyrd dumper & 110 \\
Komatsu & $\mathrm{HM} \mathrm{300-3}$ & Ramstyrd dumper & 114 \\
Komatsu & $\mathrm{HM} \mathrm{350-2}$ & Ramstyrd dumper & 109 \\
Komatsu & $\mathrm{HM} \mathrm{400-3}$ & Ramstyrd dumper & 110 \\
\hline
\end{tabular}

\section{Möjligheter till bullerdämpning:}

Ingen dumpertillverkare har satsat stort på att dämpa buller externt från dumpers. Lastflak hos lastbil/dumper kan förses med gummi vilket dämpar buller vid lastning med ca $10 \mathrm{dBA}$ jämfört utan gummibeklädnad.

\subsection{Hjullastare}

Hjullastare är vanligt förekommande i bergtäkter. Hjullastare används till att lasta ut siktat bergmaterial till lastbil, till att lasta efterkross och till att förflytta sprängsten från brytfronten i mindre täkter. Buller från drivning, luftintag och i samband med lastning och tippning är viktiga bullerkällor. Vissa ljud varierar mellan olika förare, med ett mjukare 
körsätt och anpassad teknik för att minimera skrapljud mellan skopa och mark samt urskakning av skopa påverkas bulleremissionen.

Figur 10. Exempel på hjullastare Volvo L120G. Källa: Volvo CE.

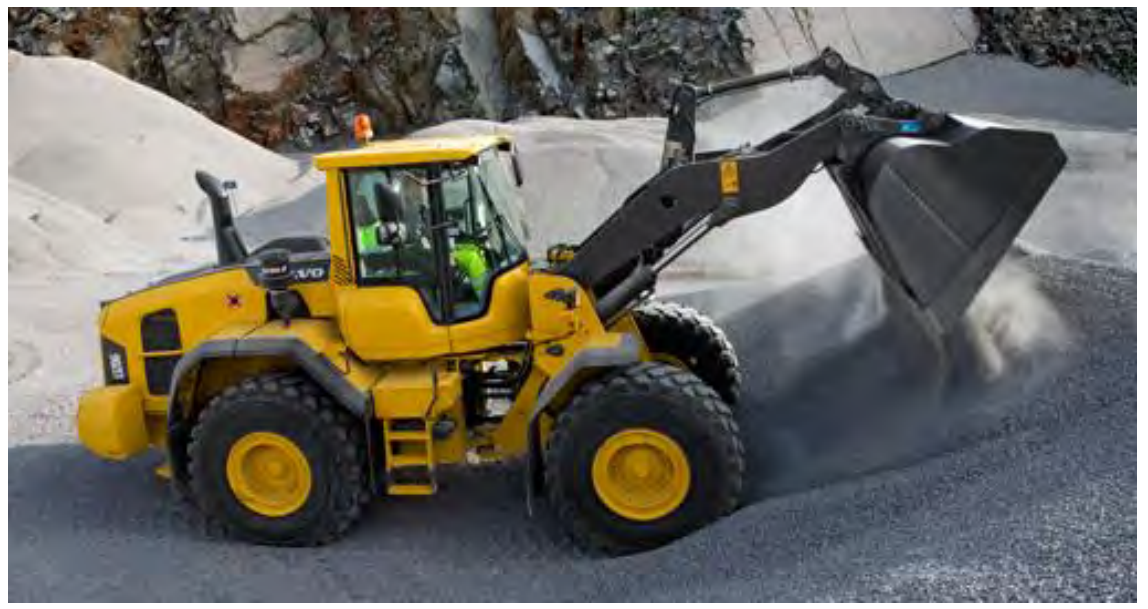

Tabell 10. Ljudeffektnivå Hjullastare

\begin{tabular}{llll}
\hline Leverantör & Modell & Typ & Ljudeffektnivå $\mathbf{L}_{\text {wA }}$ dBA \\
\hline Volvo CE & L60G & Hjullastare & 104 \\
Volvo CE & L70G & Hjullastare & 105 \\
Volvo CE & L90G & Hjullastare & 105 \\
Volvo CE & L110G & Hjullastare & 106 \\
Volvo CE & L120G & Hjullastare & 106 \\
Volvo CE & L150G & Hjullastare & 108 \\
Volvo CE & L180G & Hjullastare & 108 \\
Volvo CE & L220G & Hjullastare & 109 \\
Volvo CE & L250G & Hjullastare & 109 \\
Volvo CE & L350F & Hjullastare & 111 \\
Caterpillar & $938 \mathrm{H}$ & Hjullastare & 105 \\
Caterpillar & $950 \mathrm{H}$ & Hjullastare & 106 \\
Caterpillar & $950 \mathrm{~K}$ & Hjullastare & 107 \\
Caterpillar & $962 \mathrm{H}$ & Hjullastare & 106 \\
Caterpillar & $962 \mathrm{~K}$ & Hjullastare & 107 \\
Caterpillar & $966 \mathrm{H}$ & Hjullastare & 107 \\
Caterpillar & $966 \mathrm{~K}$ & Hjullastare & 108 \\
Caterpillar & $972 \mathrm{H}$ & Hjullastare & 108 \\
Caterpillar & $972 \mathrm{~K}$ & Hjullastare & 108 \\
Caterpillar & $980 \mathrm{H}$ & Hjullastare & 108 \\
Caterpillar & $980 \mathrm{~K}$ & Hjullastare & 109 \\
\hline
\end{tabular}

\section{Möjligheter till bullerdämpning:}

Flera tillverkare satsar på att skapa en god arbetsmiljö i hytten men ambitionen att dämpa det externa bullret är inte lika påtaglig. Från hjullastare är ofta lastmomenten som skapar det största bullret, t.ex. skrapning av lastskopan mot underlaget och lastning till lastbil eller kross/siktficka. 


\subsection{Utlastning till lastbil och transporter}

Uttransport av krossat och siktat bergmaterial sker i regel med lastbil. Bullriga moment är lastning samt själva transporterna utmed täktvägen. Som tidigare nämnts är det praxis hos tillståndsmyndigheten att transporter på täktväg också klassas som del av verksamhetsområdet och bedöms som externt industribuller fram till anslutningspunkt på det allmänna vägnätet.

Figur 11. Exempel på truckar försedda med gummiskikt på lastflaken

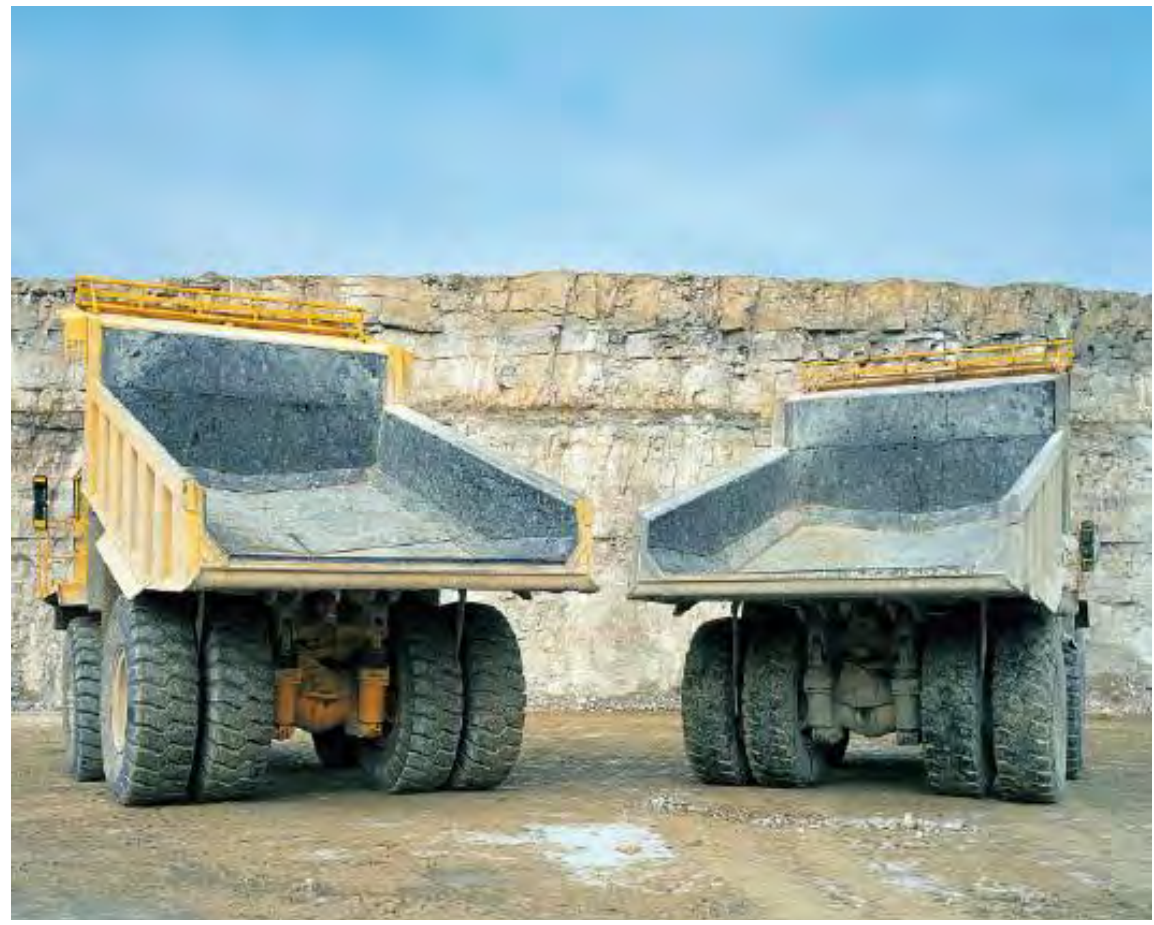

Källa: Metso.

\section{Möjligheter till bullerdämpning:}

Lastflak hos lastbil/dumper kan förses med gummi vilket dämpar buller vid lastning med ca $10 \mathrm{dBA}$ jämfört utan gummibeklädnad. Detta skapar också en lägre bullerpåverkan för både förare av hjulastare som lastbilschaufför. Exempel på leverantörer av gummibeklädnader är Metso och Sandvik.

Transportvägar utgörs ofta av grusvägar. Transporter på grusvägar genererar mer buller än transporter på asfalterad väg vid samma hastighet. Grusvägar får dessutom, med eftersatt underhåll, ojämnheter som potthål och räfflad vägyta. Med låga hastigheter på transportvägen, 
jämnt körsätt och en så jämn vägbeläggning som möjligt kan buller från transporter reduceras. Återfinns bostäder i närheten av transportvägen kan det bli nödvändigt med bullerplank för att klara bullervillkor, speciellt om uttransporter sker nattetid (före kl. 07:00). 



\section{Erfarenheter av maskiner $\mathrm{i}$ bergtäkter}

De ljuddata som redovisas i kapitel 8 har utförts under kontrollerade förhållanden. I vissa fall har arbete under last utförts i samband med mätningarna.

ÅF Ljud \& Vibrationer har via ett stort antal (>300) uppdrag för bergtäkter samlat på sig erfarenhet när det gäller bulleremissioner från maskiner i bergtäktsverksamhet. Ljudnivåer varierar kraftigt beroende på vilken typ av maskin som används och vid vilken last mätningarna utförs i täkten. I ansättning av en ljudeffektnivå hos en bullerkälla tas hänsyn till vilken drift maskinen jobbar med vilka moment som ingår i en arbetscykel. T.ex. borrning ger kraftigast bulleremission direkt vid påslaget, ljudnivån sjunker något då borrningen fortskrider sedan kommer ställtid i samband med byte till nästa borrplats. Lastfordon avger sällan den dimensionerande bullernivån från sitt eget maskineri utan det är lastmoment och tippning av material på flak $\mathrm{mm}$ som blir rådande för bullerutredningen. Det är viktigt att ta hänsyn till en representativ arbetscykel för att bestämma bulleremissionen. En grävmaskin som lastar en dumper vid brytfronten står kanske enbart på tomgång 30 \% av tiden i väntan på nästa lastning.

Nedan följer en summering om ljudnivåer och drift hos maskiner som normalt ansätts i bullerutbredningsberäkningar.

Tabell 11. Bullerkällor med uppmätt ljudeffektnivå.

\begin{tabular}{lccc}
\hline Bullerkälla & Drift & $\begin{array}{c}\text { Ljudeffektnivå i } \\
\text { dBA (re. 1 pW) }\end{array}$ & $\begin{array}{c}\text { Motsvarande ljudtrycks- } \\
\text { nivå i dBA (re. 20 } \boldsymbol{\mu P a} \text { ) på } \\
\mathbf{1 0 ~ m}\end{array}$ \\
\hline Bergborr & $80 \%$ & $118-122$ & $90-94$ \\
Grävmaskin med Hydraulhammare & $20 \%$ & $116-120$ & $88-92$ \\
Grävmaskin & $50 \%$ & $105-109$ & $77-81$ \\
Hjullastare & $50 \%$ & $103-109$ & $75-81$ \\
Dumper & $50 \%$ & $109-114$ & $81-86$ \\
Mobil förkross & $100 \%$ & $118-122$ & $90-94$ \\
Mobil efterkross med sorteringsverk & $100 \%$ & $116-120$ & $88-92$ \\
\hline
\end{tabular}




\section{Kommentar}

Extremvärden av ljudeffektnivåer i ovanstående tabell 11 samt ljudeffektnivåer från leverantörer enligt tabell 6-10 för respektive bullerkälla har använts för att skapa beräkningsfall där tystast möjligaste maskiner jämförs mot de bullrigaste.

I beräkningarna har vi antagit att krossningen är i full drift hela arbetstiden dagtid. Vad det gäller ljudemissioner från hjullastare och grävmaskin har vi i beräkningarna antagit att dessa kör med fullt gaspådrag maximalt $50 \%$ av arbetstiden.

För bergborren har vi antagit full drift ca $80 \%$ av motsvarande tid. Detta med anledning av att det i borrningsprocessen ingår avbrott i driften för byte av borrstål och förflyttning till ny borrplats.

Då det pågår skutknackning visar vår erfarenhet att man kan räkna med maximal drift ca $20 \%$ av den totala arbetstiden.

Ljudnivån från transporter beror på vägens ytförhållande, hastigheten hos fordonen samt antalet passager. 


\section{Bästa tillgängliga teknik till bullerreducering från täkter}

För en bergtäkt är det oftast borrning och krossning som är de dominerande bullerkällorna. Därför minskas bulleremissionen mest om man kan begränsa dessa källor. Generellt så ökar ljudnivån med större maskiner inom samma maskingrupp. Val av maskin och arbetskapacitet beror på vilka produktionsmål man har i täkten. Vissa maskintyper sticker dock ut där leverantörer erbjuder tystare produkter till samma kapacitet som de odämpade. I nedanstående text summeras bullerreducerande teknik som finns att tillgå för maskinell utrustning inom bergtäkt idag.

\section{Borrning}

Vid behov skärmar man av borrning genom att skapa bullervallar av avbaningsmassor. Det går också att använda lokala flyttbara skärmar, se exempel i figur nedan. De dämpade borriggarna som både Sandvik och Atlas Copco tillverkar är bra exempel på att det går att minska bulleremissionen från själva borriggen.

\section{Figur 12. Exempel på lokal bullerskärm. Källa: Järven}

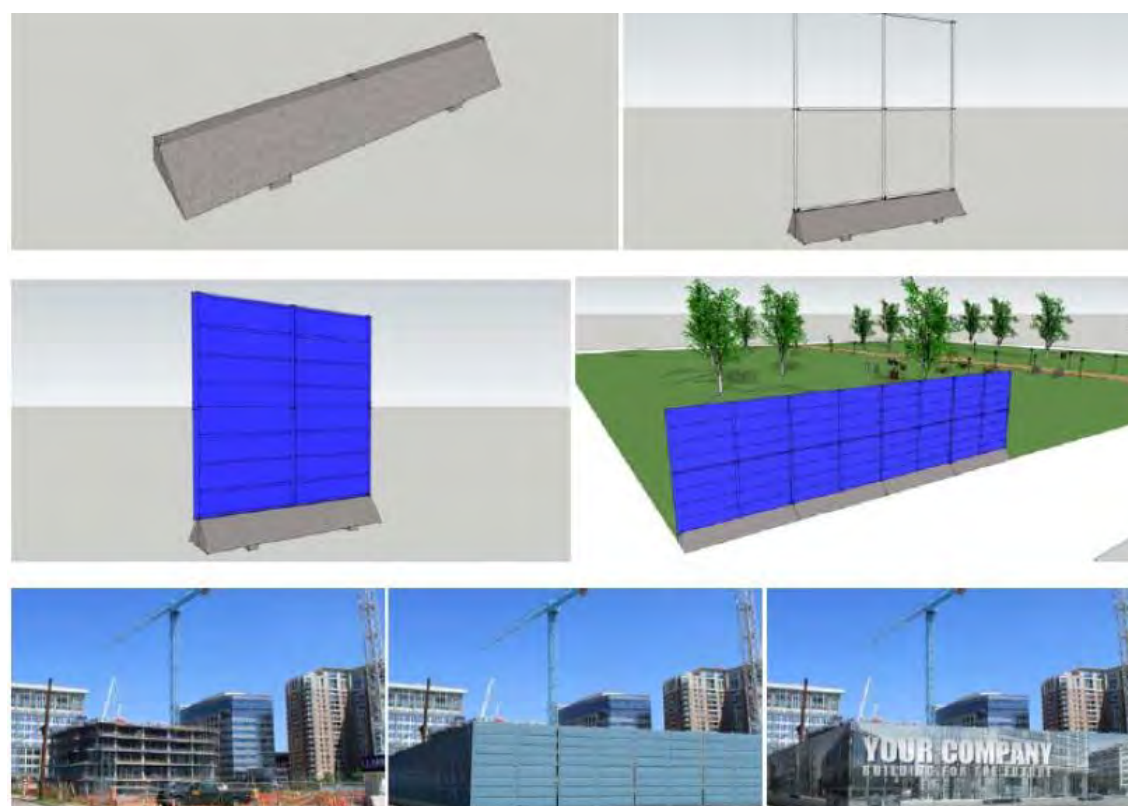


Järven Akustik har en produkt som kallas dBarrier. Produkten kan kopplas samman i flera element i 4 m längder, även i vinkel. Produktens betongfot kräver ett relativt jämnt underlag som får skapas på plats med hjälp av t.ex. grusbäddar

\section{Krossning och sorteringsverk}

Stora möjligheter finns att dämpa bulleremissionen från krossar och siktar med uppskattningsvis ca $10 \mathrm{dBA}$ genom åtgärder på huvudsakliga bullerkällor hos maskinerna. Inbyggnader eller avskärmad placering är idag den vanligaste bullerdämpningsmetoden.

\section{Lastmaskiner}

Dämpning av luftintag och gummibeklädnad/sandwichplåt av flak och eventuellt skopor är exempel på åtgärder som kan dämpa bulleremissionen från lastmaskiner ytterligare. Hos lastmaskiner har också föraren stor inverkan på bulleremissionen genom olika metoder för lastning, tippning etc. Med ett mjukt sätt att köra samt att tippning görs från så låg höjd som möjligt, kan buller minskas avsevärt. De tystaste maskinerna är också de minsta.

\section{Linsågning}

Linsågning används inom stenindustrin där man önskar få ut så hela block som möjligt för vidare kapning i produktionsstycken. Genom att borra ett fåtal borrhål kan en wire föras in i de sammanlänkade borrhålen för att såga ut blocket. Metoden minskar behovet av antal borrhål och sprängning jämfört med konventionell spränghålsborrning i en bergtäkt. Linsågning används mer och mer på anläggningssidan för att skapa rena bergsskärningar och för att undvika de vibrationer och sprickbildning som traditionell lossprängning genererar.

Linsågning är en relativt billig metod jämfört borrning. Sågning är även en tyst metod för att bearbeta berg. Sågen befinner sig alltid på täkt/pallbotten vilket ger god skärmning av pallen. Linsågning används dock inte i bergtäkter där losshållning av berg sker uteslutande genom borrning och sprängning.

I ett framtida scenario kan linsågning $\mathrm{i}$ bergtäkter ha en teoretisk framtid. Bergtäkter kan tillämpa denna metod av ekonomiska, miljömässisa och säkerhetsmässiga skäl. Med hjälp av linsågning kan relativt tunna skivor av berg sågas som blir krossbara i en slags primärkross. Denna metod minskar kraftigt antalet erforderliga borrhål och ta bort sprängningsmomentet. Behovet av sprängmedel och de problem som användande av sprängmedel innebär försvinner. T.ex. problem med odetonerat sprängmedel (s.k. dola), dvs. sprängmedel som av olika orsa- 
ker inte har detonerat och kan finnas kvar i borrhålet eller i det lossprängda berget.

Linsågning kan i många lägen användas dygnet runt om man enbart ser till möjligheter att uppfylla bullervillkor till omgivningen. Metodens effektivitet att ersätta borrning och sprängning är inte utredd men ett jämnare styckefall jämfört sprängning borde vara möjligt att skapa.

Figur 13. Linsågning. Källa Atlas Copco

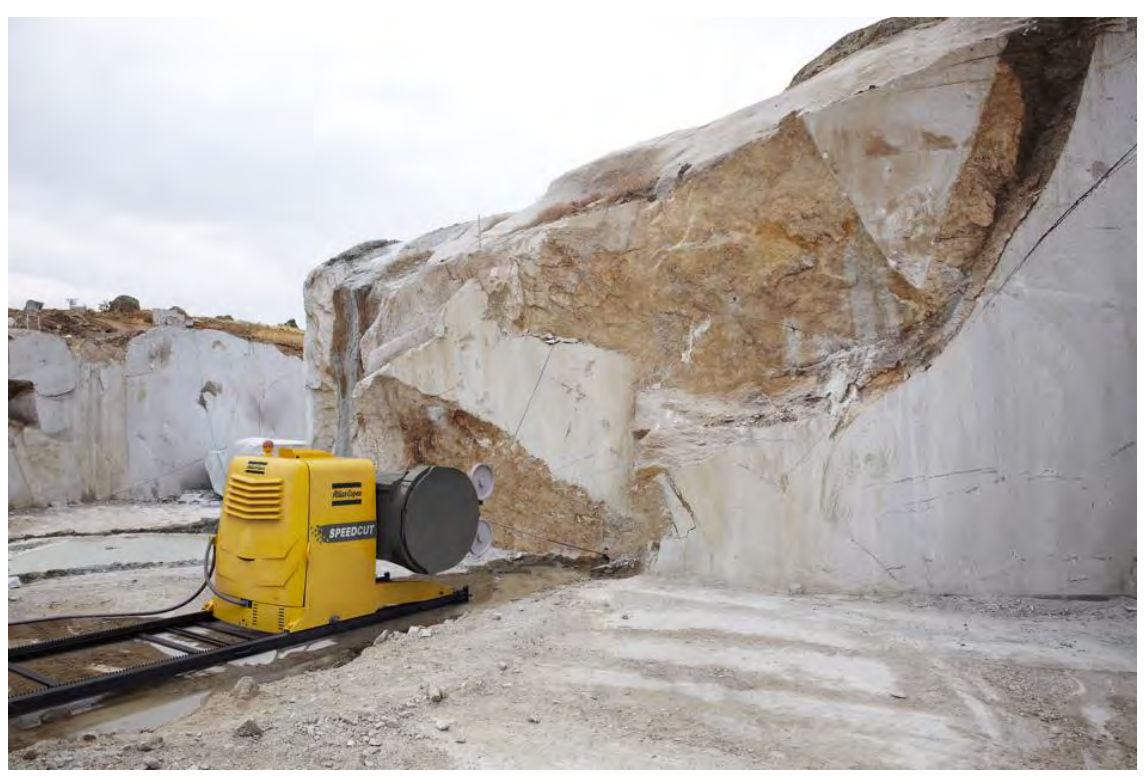





\section{Beräkning av buller från fiktiv bergtäktverksamhet}

Beräkning av buller från en fiktiv bergtäktsverksamhet har utförts för att grafiskt och i tabellform visa hur ljudnivåer till omgivningen påverkas av hur verksamheten tar hänsyn till bästa tillgängliga teknik vad gäller tyst utrustning samt möjligheter att avskärma buller.

\subsection{Beräkningsmetod}

Beräkningarna av buller från bergtäktverksamheten är baserade på en gemensam nordisk modell för beräkning av externt industribuller, DAL32 [3] Beräkningarna genomförs i oktavband och avser ett s.k. "medvindsfall," dvs. vindriktning från källa till mottagare $\left( \pm 45^{\circ}\right)$. Som hjälpmedel har använts datorprogrammet SoundPlan ver. 7.0 där ovanstående beräkningsmodell ingår.

Beräkningsmodellens osäkerhet ligger inom ca +/- $2 \mathrm{dBA}$.

\subsection{Underlag/beräkningsutförande}

Beräkningsgången kan kort beskrivas enligt följande:

- Digitalt kartunderlag, över brytningsområdet och dess omgivning har använts som grunddata i programmet. Utgående från kartunderlaget har samtliga betydande externbullerkällor matats in i kartans koordinatsystem.

- Bullerkällornas utstrålade ljudeffektnivå har lagts in som källdata.

- Beräkningsprogrammet tar hänsyn till de ytor och byggnader som befinner sig i närheten av källorna samt utefter ljudets utbredning i omgivningen. Detta innebär att eventuella ljudreflektioner eller skärmningar som påverkar ljudutbredningen från respektive källa räknas in automatiskt.

- Övriga ljuddämpande parametrar som ingår i beräkningen är dämpning på grund av avståndet, atmosfärsdämpning, 
markdämpning (hård eller mjuk mark), vegetationsdämpning samt skärmning på grund av olika byggnader i området.

- Hård mark har ansatts inom bergtäkten samt på vägar. Mjuk mark har ansatts på övriga ytor.

- Skog är inte medtaget i bullerberäkningarna pga. man i bullerutredningen inte kan utesluta att skogen kan komma att avverkas i en längre tidshorisont.

- Resultatet redovisas som beräknade totala ljudimmissionsnivåer vid mottagarpunkt samt som så kallade bullerspridningskartor i färg där nivågränser i steg om $5 \mathrm{dBA}$ redovisas.

\subsection{Maskinell utrustning}

Den maskinella utrustningen för den fiktiva verksamheten redovisas geografiskt placerade i täkten i figur 14, 15 och 16. Figur 14 och 15 visar bergtäkt i inledande skede, innan utsprängning påbörjats. Figur 16 visar skede där täktbotten och täktkanter har skapats inom täktverksamheten.

I verksamheten har följande utrustning ingått i beräkningarna:

- 1 st. normal borrigg för borrning av spränghål. Borrningen sker beräkningsmässigt i höga marknivåer vid brytfronten vilket är dimensionerande för bullerutbredningen.

- 1 st. grävmaskin försedd med hydraulhammare för att knacka skut.

- 1 st. grävmaskin för lastning av förkross samt verksam vid brytfront.

- 2 st. hjullastare för lastning av efterkross, vid brytfront samt utlastning till lastbil.

- 1 st. mobil förkross.

- 1 st. mobil efterkross och sorteringsverk.

- Uttransporter av material sker med lastbilar som trafikerar transportväg för anslutning till det allmänna vägnätet norr om verksamhetsområdet. 
Figur 14. Maskinpositioner och transportvägar inom täktområde inledande, planskiss

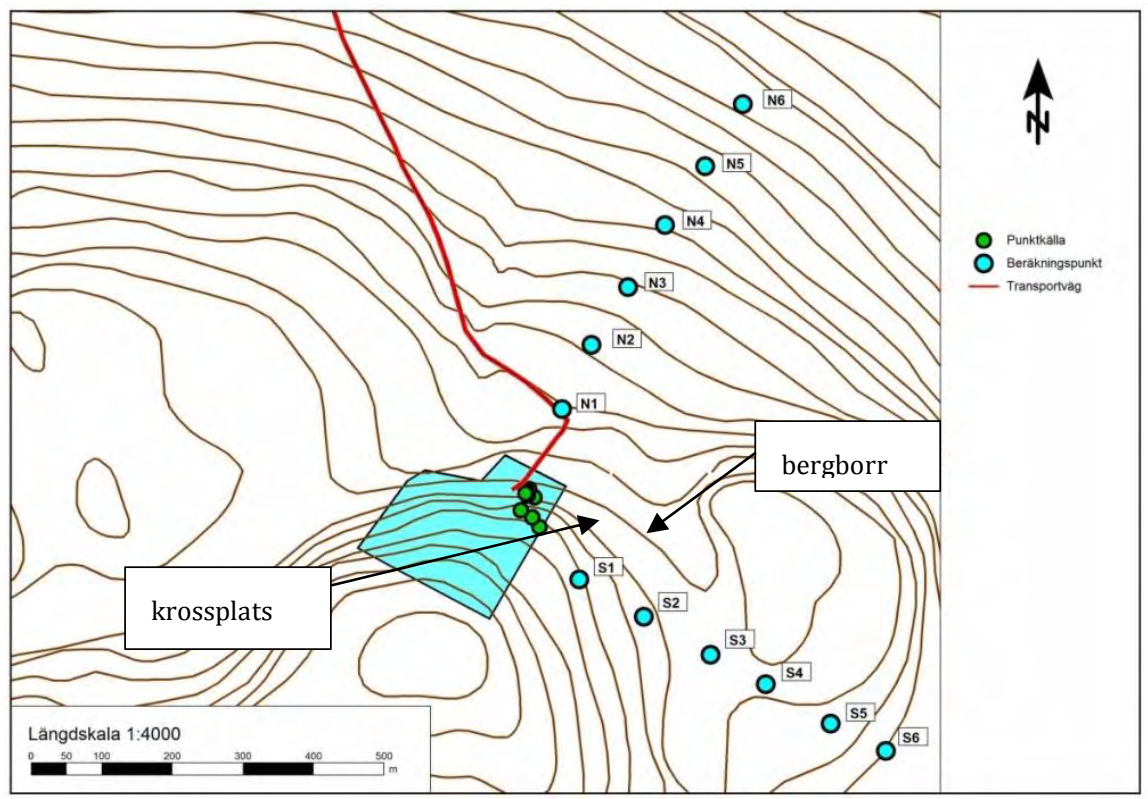

Figur 15. Maskinpositioner och transportvägar inom täktområde inledande, vy i 3D

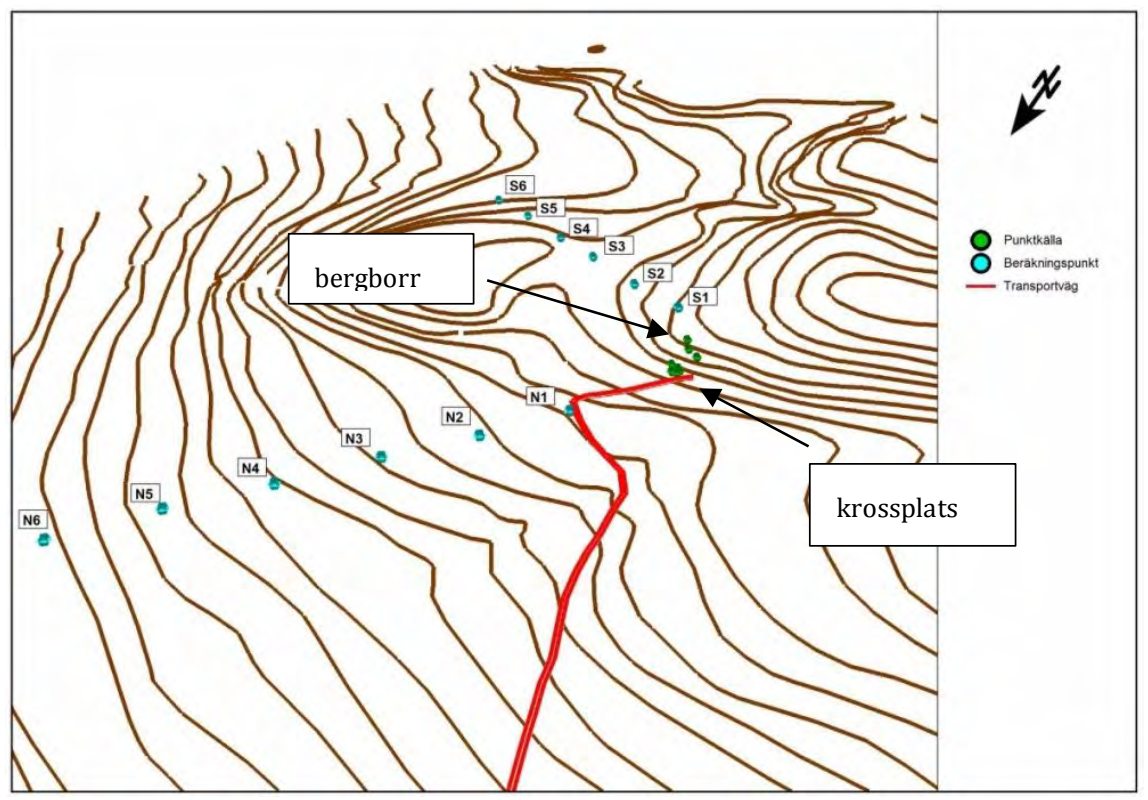


Figur 16. Maskinpositioner och transportvägar inom täktområde med skapad täktbotten, vy i $3 D$

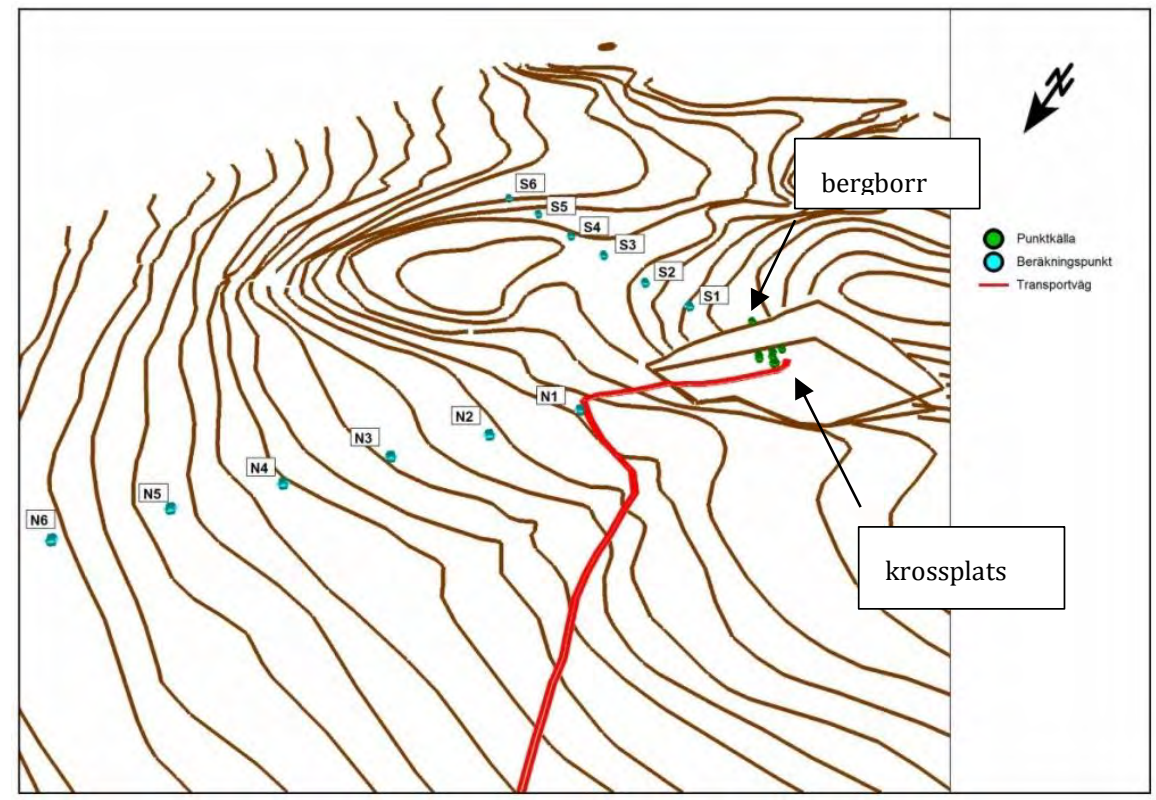

Tabell 12. Bullerkällor ingående i beräkningar med antagen ljudeffektnivå

\begin{tabular}{lcccc}
\hline Bullerkälla & Antal & Drift & $\begin{array}{r}\text { Ljudeffektnivå i dBA } \\
\text { (re. 1 pW) i karaktär } \\
\text { "bullrigast" }\end{array}$ & $\begin{array}{r}\text { Ljudeffektnivå i } \\
\text { dBA (re. 1 pW) i } \\
\text { karaktär "tystast" }\end{array}$ \\
\hline $\begin{array}{l}\text { Bergborr (normal och dämpad rigg) } \\
\text { Grävmaskin med Hydraulhammare }\end{array}$ & 1 & $80 \%$ & 122 & 112 \\
$\begin{array}{l}\text { Grävmaskin } \\
\text { Hjullastare }\end{array}$ & 1 & $50 \%$ & 124 & 116 \\
$\begin{array}{l}\text { Utlastning till lastbil (med och utan } \\
\text { dämpat flak) }\end{array}$ & 1 & $20 \%$ & 109 & 104 \\
$\begin{array}{l}\text { Mobil förkross } \\
\text { Mobil efterkross med sorteringsverk }\end{array}$ & 1 & $100 \%$ & 109 & 100 \\
$\begin{array}{l}\text { In- och uttransporter på grusväg } \\
\text { respektive asfaltsbeläggning ger } \\
\text { bullrigaste resp. tystaste underlaget }\end{array}$ & 40 & $30 \mathrm{~km} / \mathrm{h}$ & 110 & 118 \\
\hline
\end{tabular}

*Sikt antaget försett med dämpade gummigaller. 


\subsection{Beräkningsfall}

Beräkningarna har indelats i 11 olika beräkningsfall.

Tabell 13. Beräkningsfall 1-8

\begin{tabular}{|c|c|c|c|c|c|c|}
\hline Fall & Antal källor & Placering borr & $\begin{array}{l}\text { Placering } \\
\text { övrigt }\end{array}$ & $\begin{array}{l}\text { Skärmar och } \\
\text { vallar }\end{array}$ & Transportväg & $\begin{array}{l}\text { Karaktär } \\
\text { bullerkällor }\end{array}$ \\
\hline 1 & alla & högt & ytberget & nej & grus & bullrigast \\
\hline 2 & alla & högt & ytberget & ja & asfalt & tystast \\
\hline 3 & ej borr & & ytberget & nej & grus & bullrigast \\
\hline 4 & ej borr & & ytberget & ja & asfalt & tystast \\
\hline 5 & alla & högt & täktbotten & nej & grus & bullrigast \\
\hline 6 & alla & högt & täktbotten & ja & asfalt & tystast \\
\hline 7 & ej borr & & täktbotten & nej & grus & bullrigast \\
\hline 8 & ej borr & & täktbotten & ja & asfalt & tystast \\
\hline Tab & 1) Prälni & & & & & \\
\hline Fall & Antal källor & Placering borr & $\begin{array}{l}\text { Placering } \\
\text { övrigt }\end{array}$ & $\begin{array}{l}\text { Skärmar och } \\
\text { vallar }\end{array}$ & Täktkant & $\begin{array}{l}\text { Karaktär } \\
\text { bullerkällor }\end{array}$ \\
\hline 9 & ej borr & & täktbotten & nej & rak & bullrigast \\
\hline 10 & ej borr & & täktbotten & nej & konvex & bullrigast \\
\hline 11 & ej borr & & täktbotten & nej & konkav & bullrigast \\
\hline
\end{tabular}

\subsection{Beräkningspunkter}

Beräkningar av det totala ljudimmissionsbidraget från täkten och från lastbilstrafiken på täktvägen har utförts till 12 st. fiktiva fastigheter, NO och SO om bergtäkten. Fastigheterna visas i figur 14-16 ovan. Fastigheterna är belägna inom 100-600 m från bergtäkten. S1 och N1 är belägna ca $100 \mathrm{~m}$ från täkt och motsvarande upp till $600 \mathrm{~m}$ avstånd för S1 respektive N6. 



\section{Beräkningsresultat}

Tabell 15 redovisar beräknade ekvivalenta ljudnivåer för olika åtgärder och verksamheter i en fiktiv bergtäkt inklusive lastbilstrafik på täktvägen. Redovisade värden i varje beräkningspunkt avser frifältsvärden. Se beskrivning av varje beräkningsfall i kap 11.4.

Tabell 15. Beräknade bullernivåer i beräkningsfall 1, avbaning

\begin{tabular}{llllllllllllll}
\hline \multirow{2}{*}{ Fall } & \multicolumn{8}{c}{ Beräknad ekvivalent ljudtrycksnivå, dBA för respektive beräkningspunkt } & & & \\
& N1 & N2 & N3 & N4 & N5 & N6 & S1 & S2 & S3 & S4 & S5 & S6 \\
\hline 1 & 71 & 65 & 63 & 58 & 56 & 52 & 70 & 61 & 57 & 55 & 52 & 53 \\
2 & 63 & 58 & 56 & 50 & 49 & 45 & 60 & 52 & 48 & 45 & 42 & 41 \\
3 & 70 & 64 & 62 & 57 & 55 & 51 & 63 & 54 & 53 & 51 & 49 & 51 \\
4 & 62 & 58 & 55 & 50 & 49 & 44 & 55 & 45 & 44 & 42 & 39 & 39 \\
5 & 64 & 63 & 60 & 54 & 53 & 51 & 69 & 61 & 56 & 53 & 49 & 47 \\
6 & 52 & 51 & 47 & 42 & 40 & 39 & 59 & 51 & 46 & 43 & 40 & 38 \\
7 & 62 & 61 & 59 & 53 & 52 & 49 & 44 & 44 & 42 & 40 & 37 & 35 \\
8 & 50 & 49 & 45 & 39 & 38 & 37 & 40 & 40 & 38 & 35 & 33 & 31 \\
9 & 61 & 60 & 58 & 55 & 52 & 50 & 44 & 44 & 41 & 39 & 37 & 35 \\
10 & 61 & 60 & 58 & 55 & 52 & 51 & 45 & 44 & 41 & 39 & 37 & 35 \\
11 & 62 & 61 & 59 & 55 & 52 & 50 & 44 & 44 & 41 & 39 & 37 & 35 \\
\hline
\end{tabular}

\section{Kommentar}

Färgskalan i tabellen ovan är ritad med samma bullerintervall som i bilagor. Grönt indikerar ljudnivåer $50 \mathrm{dBA}$ och under. Gult indikerar 50$55 \mathrm{dBA}$, rött 55-60 dBA och lila över $60 \mathrm{dBA}$. 
Figur 17. Jämförelse bullrigaste-tystaste, beräkningsfall 1 och 2
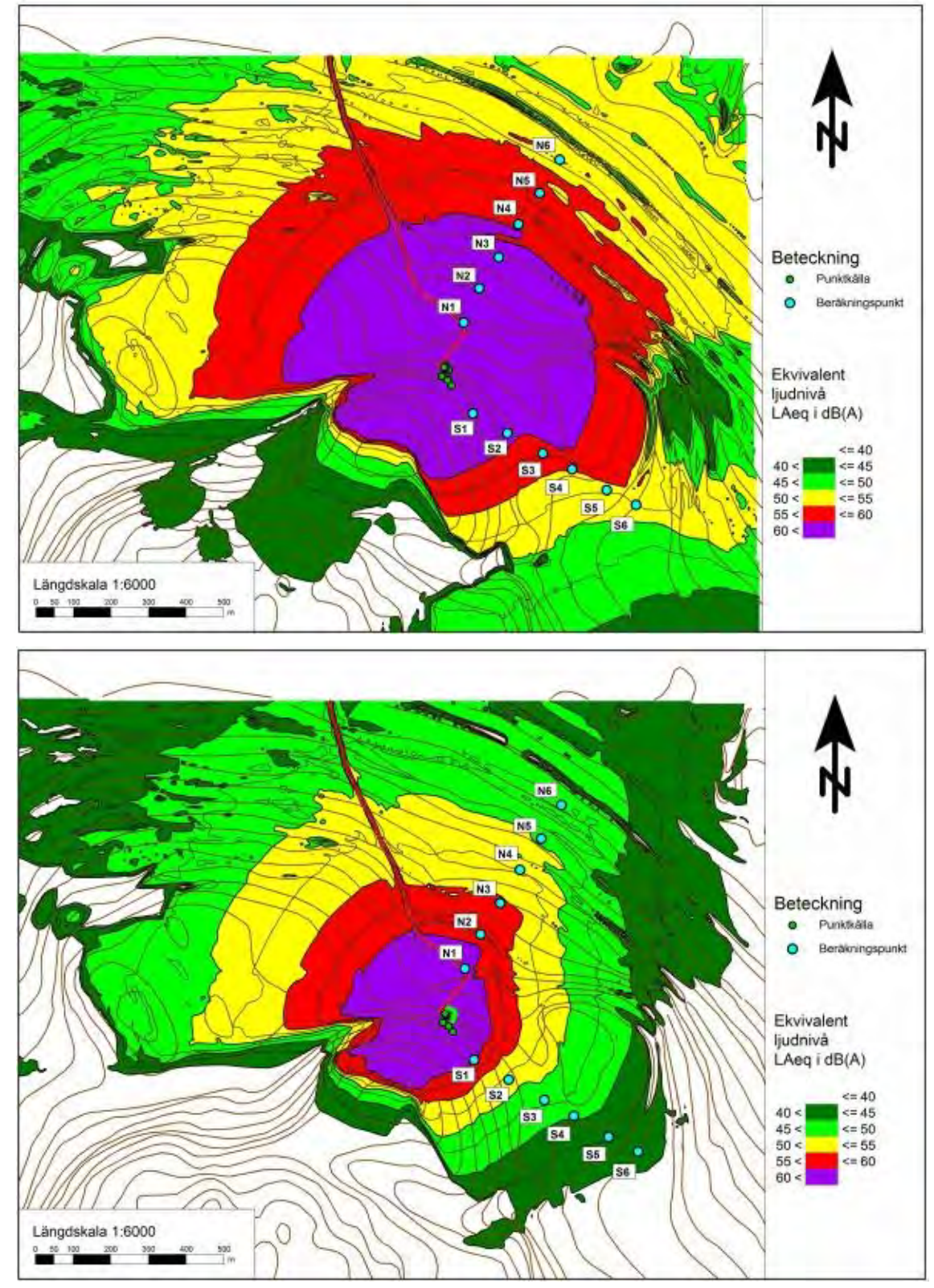
Figur 18. Jämförelse bullrigaste-tystaste, beräkningsfall 5 och 6
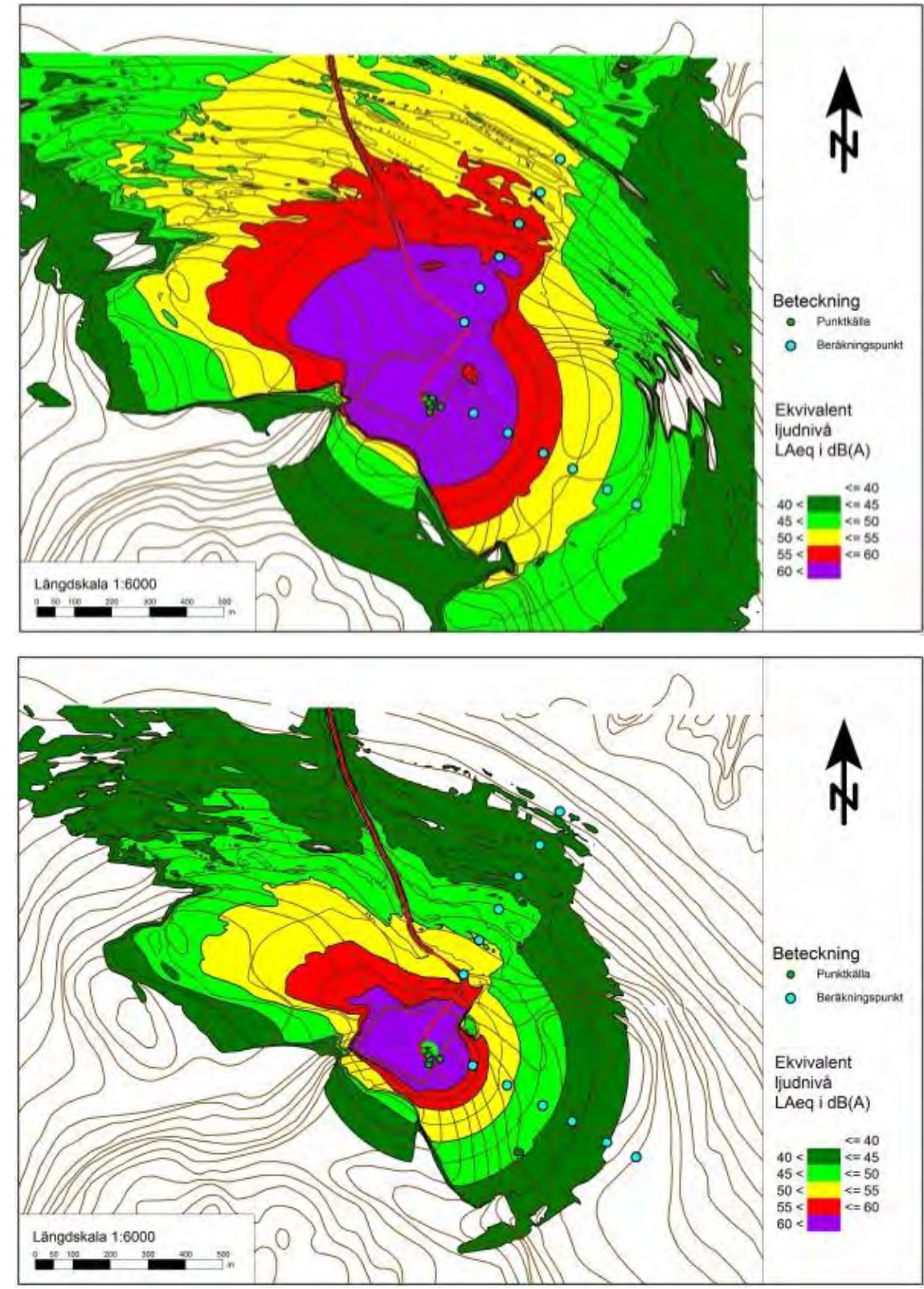
Man kan se flera intressanta resultat i ovanstående beräkningsresultat:

- Endast beräkningsfall 8 ger nivåer under 50 för samtliga beräkningspunkter. Det är verksamhet utan borrning, med tystast möjliga utrustning, med extra vallar och skärmar samt nere i täktbotten bakom täktkanter.

- Beräkningspunkter N1-N3 har ljudnivåer överskridande 50 dBA utom i beräkningsfall 8. Punkterna ligger åt motsatt håll som drivningsriktningen vilket aldrig ger dessa punkter avskärmning av pall vid brytfront.

- För punkt S1-S6 dominerar buller från borrning speciellt när krossplatsen är skärmad av täktkant. För närliggande fastigheter S1S2 krävs extra åtgärder för att dämpa borrning utöver dämpad borrigg. För odämpad borrigg och utan annan dämpåtgärd krävs ett avstånd på minst $500 \mathrm{~m}$ för att understiga $50 \mathrm{dBA}$.

- Det är stor skillnad på beräkningsfall 7-8 för beräkningspunkterna N1-N6. Skärmar och vallar ger god dämpning mot dessa punkter se beräkningsfall 8 Punkterna i sydost får en skärmning av täktkant vilket kraftigt minskar bullerspridning åt detta håll.

- Resultatet visar att en tillämpning av "Best Available Technique" d.v.s vid ett systematiskt arbete med buller i bergtäkters planering och pågående verksamhet kan ljudutbredningen till omgivningen minskas betydligt. Avståndet från täkt till punkt i omgivningen där riktvärdet överskrids kan halveras för den bullrigaste situationen jämfört med den dämpade. Detta innebär i sin tur att området som överstiger riktvärdet kan teoretiskt, med rätt topografiska förutsättningar, minska ned till en fjärdedel med användning av "Best Available Technique." 


\section{Slutsatser}

BAT avseende buller från bergtäktsverkasamhet kan sammanfattas enligt följande:

- Det är alltid rekommenderat att styra brytningsriktning så att topografisk nivåskillnad bildas mellan täktbotten vid brytfront och närmaste bostäder. Detta kommer att ge en betydligt högre möjlighet att skärma av t ex krossar vilket gör att ljudnivåbidraget från dessa maskiner till omgivande bostäder minskas.

- Avbaningsmaterial kan med fördel användas för att bygga upp permanenta eller tillfälliga bullervallar mellan borrning och bostäder. Bullervallen bör vara placerad så nära borrningen som möjligt.

- Det är mest effektivt att utföra bulleråtgärder direkt på källan då det ger effekt för flera utbredningsriktningar och bergtäktsentreprenören får en större frihet i sitt arbete och behöver inte fokusera på att bygga upp och arbeta bakom t.ex. bullervallar för att innehålla bullervillkor till omgivningen. Att åtgärda vid källan skapar också bättre ljudmiljö vid arbetsplatserna för den personal som hanterar borrigg, grävmaskin, hjullastare, och övriga maskiner i täkten.

a) Typiska principåtgärder för att dämpa buller vid källan är:

- Val av tystare maskin.

- Val av tystare arbetsmetod.

- Påverka störkrafter, göra processen mjukare med kortare fallhöjder etc.

- Minska ljudutstrålning från vibrerande ytor.

- Kontinuerligt underhåll.

- I en bergtäkt har man normalt stora upplag av olika grusfraktioner. Upplagen kan ha en betydande bulleravskärmande verkan av maskiner i täkten om upplagens storlek och utbredning är tillräckligt stor. Placeringen av krossplats och upplagshögar bör beaktas för at få bästa möjliga bullerdämpning.

- Transportvägar kan med fördel asfaltbeläggas. Detta minskar buller samt damm till närboende. Hastigheten på täktvägen bör begränsas till ca $30-50 \mathrm{~km} / \mathrm{h}$ nära bostäder. 



\section{Referenser}

1) Externt industribuller - Allmänna råd, RR 78:5 rev, 1983, Naturvårdsverket

2) MinBaS II delprojekt 3.1a-2 buller - Slutrapport, november 2010

3) Kragh J, Andersen B, Jacobsen J:"Environment noise from industrial plants. General prediction method." Lydteknisk laboratorium, Denmark. Report no. 32, 1982 



\section{Summary}

ÅF Sound \& Vibration has been commissioned by the Nordic Council of Ministers BAT group (which is an under group to the NCM working group on Sustainable Consumption and Production) to study the BAT (Best Available Technique) to minimize noise from rock quarries. Noise is one of the greatest environmental concerns for aggregate industry that supplies materials for building, road and railway construction, as well as for use in certain chemical processes and in environmental studies. The raw material is crushed rock, gravel, natural sand, boulders and recycled materials. Quarry operations require permits and an approved environmental impact assessment by the relevant authority.

The aim of the study is to show how noise propagation can vary from a quarry depending on the choice of machinery and the application of best available technology. Approximate noise limits, figures, terms and methods are relatively similar in the Nordic countries, but there are differences. Results and discussion focuses on the sound power that different machines and operations generate, and what is normally done and could be reflected in a rock quarry to reduce noise emission to the surrounding area. Estimated noise levels are based on the measured sound power levels of machines in operation. The strongest continuous sources of noise in a rock quarry are normally rock crushing and drilling.

The results are presented as a prediction of the external noise from a fictional rock quarry by a real topographic model. The calculations are based on tabulated sound power data on existing machine equipment and an assumed excavation plan. Expected equivalent sound levels are estimated at a total of 12 reference points in the surrounding area. The calculations also include the noise contribution of road transport to and from the quarry area. The calculations relate to 11 different calculation cases for quarry operations where the following parameters have been varied:

- Noisiest to least noisy machinery within a medium sized quarry.

- With or without screens/dykes near machinery.

- Dirt track or asphalt coating on the route between revenues and connection point on the public road network. 
- Mineral and mining operations on unshielded supra crustal rocks compared to the revenue base near the quarry edge.

- Calculations with and without drilling. The drilling in the noise calculations is always placed high on the rock surface, not on the lower level near the pit bottom.

- Calculations for machines on pit bottom were also performed with straight, concave or convex refractive rock front, to show the effect of different geometries.

The results show that application of "Best Available Technique" reduces the environmental impact regarding noise significantly. The distance from the quarry to the point near where the target value is exceeded can be reduced by $50 \%$. This in turn means that the area exceeding the target value, in case of good topographical conditions, can be reduced down to $25 \%$ by use of "Best Available Technique." 
Nordiska ministerrådet

Ved Stranden 18

DK-1061 København K

www.norden.org

\section{Best Available Technique}

Buller från bergtäkter

På uppdrag av Nordiska ministerrådet har ÅFs experter inom ljud och vibrationer utvärderat bästa tillgängliga teknik (BAT-Best Available Technique) avseende buller från bergtäkter. Syftet är att visa hur bullerutbredningen kan variera från en bergtäkt beroende på val av maskinutrustning och tillämpning av bästa möjliga teknik. Riktvärden, villkor och mätmetoder är relativt lika i de Nordiska länderna, men skillnader finns. Analysen fokuserar på de ljudeffekter som olika maskiner och verksamheter ger upphov till, samt vad som normalt görs och kan beaktas i en bergtäkt för att minska bullerspridning till omgivningen. Resultatet visar att med tillämpning av bästa tillgängliga teknik (BAT) kan ljudutbredningen till omgivningen minskas betydligt. Avståndet från täkt till punkt i omgivningen där riktvärdet överskrids kan då halveras jämfört med den bullrigaste situationen. Detta innebär att området som överstiger riktvärdet, med rätt topografiska förutsättningar och tillämpning av BAT, kan minskas ned till en fjärdedel.
TemaNord 2013:588

ISBN 978-92-893-2662-9

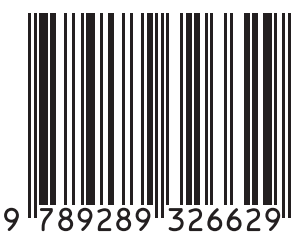

